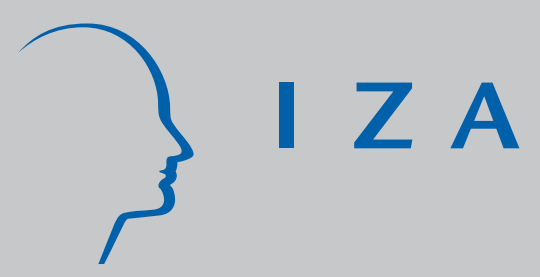

IZADP No. 2776

Household Choices of Child Labor and Schooling:

A Simple Model with Application to Brazil

Diana Kruger

Rodrigo R. Soares

Matias Berthelon

May 2007 


\title{
Household Choices of Child Labor and Schooling: A Simple Model with Application to Brazil
}

\author{
Diana Kruger \\ Pontificia Universidad Católica de Valparaíso \\ Rodrigo R. Soares \\ University of Maryland, Catholic University of Rio de Janeiro, \\ NBER and IZA \\ Matias Berthelon \\ Pontificia Universidad Católica de Valparaíso
}

Discussion Paper No. 2776

May 2007

IZA

P.O. Box 7240

53072 Bonn

Germany

Phone: +49-228-3894-0

Fax: +49-228-3894-180

E-mail: iza@iza.org

\begin{abstract}
Any opinions expressed here are those of the author(s) and not those of the institute. Research disseminated by IZA may include views on policy, but the institute itself takes no institutional policy positions.

The Institute for the Study of Labor (IZA) in Bonn is a local and virtual international research center and a place of communication between science, politics and business. IZA is an independent nonprofit company supported by Deutsche Post World Net. The center is associated with the University of Bonn and offers a stimulating research environment through its research networks, research support, and visitors and doctoral programs. IZA engages in (i) original and internationally competitive research in all fields of labor economics, (ii) development of policy concepts, and (iii) dissemination of research results and concepts to the interested public.
\end{abstract}

IZA Discussion Papers often represent preliminary work and are circulated to encourage discussion. Citation of such a paper should account for its provisional character. A revised version may be available directly from the author. 


\section{ABSTRACT}

\section{Household Choices of Child Labor and Schooling: A Simple Model with Application to Brazil*}

This paper develops and estimates a simple structural model of household decisions regarding child labor and schooling. We argue that part of the conflicting results from the previous literature - related to the effect of improvements in economic conditions on child labor - derives from the different income and substitution effects implicit in different types of income variation. Our model leads to an empirical specification where income and substitution effects can be clearly identified. We apply our model to Brazil and use agricultural shocks to local economic activity (coffee and overall agricultural production) to distinguish between the effects of increases in household income and increases in the opportunity cost of children's time. The results show that higher parental wages and household wealth are associated with lower child labor and higher school attendance. Nevertheless, conditional on family income and socioeconomic status, exogenous temporary increases in local economic activity are associated with increased opportunity cost of children's time and, therefore, higher child labor and lower schooling. The results reconcile economic theory with seemingly contradictory evidence from the previous empirical literature.

JEL Classification: D13, J22, 012

Keywords: child labor, schooling, generalized ordered logit, Brazil

Corresponding author:

Rodrigo R. Soares

Department of Economics

University of Maryland

3105 Tydings Hall

College Park, MD 20742

USA

E-mail: soares@econ.umd.edu

\footnotetext{
* This paper benefited from the excellent research assistance of Daniela Zapata, and from comments from Marta Rubio Codina, Áureo de Paula, Claudia Sanhueza, Richard Williams, and seminar participants at the 2006 Northeast Universities Development Consortium Conference (NEUDC 2006, Cornell University), the XXVIII Meeting of the Brazilian Econometric Society (SBE 2006, Salvador), Fordham University, IPEA-Rio, Universidad de Chile, and UFRGS-PPG. Kruger and Berthelon received financial support from the Comisión Nacional de Investigación Científica y Tecnológica (CONICYT), Chile, through FONDECYT Project No. 1050436 and International Cooperation Grant No.7050212. The usual disclaimer applies.
} 


\section{Introduction}

This paper develops and estimates a simple structural model of household decisions regarding child labor and schooling. Though both the theoretical and empirical literatures on child labor have blossomed in recent years, there remains a gap between the two. We argue that part of the conflicting results obtained in the empirical literature - related to the effect of improvements in economic conditions on child labor - derives from its lack of theoretical structure. Our model leads to an empirical specification where the income and substitution effects from different components of family income can be clearly identified. We show that the effects of these components are different according to the margin of choice faced by the family, and incorporate these restrictions in the estimation. As expected, our empirical results using Brazilian data show that family wealth tends to reduce the incidence of child labor and increase school attendance, while, conditional on family wealth, increases in economic activity (or in the opportunity cost of children's time) are associated with increased child labor and reduced school attendance. Most of the conflicting results from the previous empirical literature can be easily understood as a consequence of its incapacity to distinguish between the income and substitution effects implicit in different types of income variation.

Child labor has been identified as an important determinant of the persistence of poverty in developing countries. Inefficiently high levels of child labor - due to credit constraints or to general equilibrium effects on wages - reduce human capital accumulation by children, therefore reducing future wages and reproducing poverty and inequality. Baland and Robinson (2000) show that, even when socially inefficient, child labor may exist due to the incapacity of parents to borrow against the future income of children. Basu and Van (1998), in a multiple equilibria model, stress an alternative mechanism in which child labor is both a cause and a consequence of poverty: in a "good" equilibrium, when market wages are high, parents choose not to send their children to work; whereas in a "bad" equilibrium, when wages are low and families are poor, parents send their children into the labor force. Along similar lines, Dessy (2000) finds that there is a critical level of adult wages below which child labor is supplied. ${ }^{1}$ Ranjan (2001) also shows that credit constraints lead to inefficiently high levels of child labor, which, in turn, are related to greater income inequality.

\footnotetext{
${ }^{1}$ An exception in the theoretical literature is the model developed by Rogers and Swinnerton (2004), where lowincome parents who anticipate future transfers from their children invest more in children's present education, whereas high-income parents do not expect or need such transfers and, therefore, invest less in the human capital of children. Though theoretically consistent, this model does not seem particularly relevant to analyze the current situation in most developing countries.
} 
In these models, the market solution leads to a situation where it would be socially efficient to reduce children's labor supply and increase schooling. In such settings, child labor can be an intergenerational source of poverty traps: poor children work today, obtain less schooling and become low productivity workers, earning low wages in the future (as suggested by the evidence presented in Emerson and Souza, 2003). ${ }^{2}$

Empirical work on the determinants of child labor has spanned a wide range of different settings and experiments. Edmonds (2005a and 2005b), for example, finds that improvements in economic status explain most of the decline in child labor in Vietnam, while anticipated cash transfers to the elderly in South Africa are associated with increased schooling and reduced labor supply by children. Bourguignon et al (2003) and Cardoso and Souza (2004) find that, in Brazil, conditional income transfers from the Bolsa Escola program increased the likelihood of schooling, but had no significant impact on the incidence of child labor. ${ }^{3}$ Beegle et al (2006) find that, in Tanzania, negative agricultural shocks (reports of value of crop losses due to insects, rodents, and other calamities) increase the number of hours worked by children and reduce school enrollment; they also show that households with a sufficiently high level of assets are able to fully offset the shocks. These results suggest that poverty and liquidity constraints are important determinants of household decisions regarding children's allocation of time.

But other empirical evidence reaches conclusions that may seem puzzling at first sight. Barros et al (1994) find that, in the eight largest metropolitan areas of Brazil, child labor is higher during periods of low poverty and high economic growth, rather than during periods of economic downturns and high poverty. Similarly, also looking at urban Brazil, Neri and Thomas (2001) find that children are more likely to repeat a grade and more likely to work during periods of economic growth, while Duryea and Arends-Kuenning (2003) find that incidence of child labor is higher and educational outcomes are worse when average wages are higher. Kruger (2006a and 2006b) finds that, in coffee producing regions of both Brazil and Nicaragua, children are more likely to work and less likely to go to school during periods of improved economic conditions due to coffee booms. Results such as these have led some authors - such as Barros et al (1994) and Rogers and Swinnerton (2004) - to argue that there is at best a weak link between income and child labor, and to question whether poverty and credit constraints are indeed the sources of the problem.

\footnotetext{
${ }^{2}$ Although most of the empirical literature has focused on the relationship between child labor and school attainment or enrollment, Gunnarsson et al. (2006) find that child labor leads to lower standardized test scores among grade school children of nine Latin American countries, thus harming the quality of schooling as well.

${ }^{3}$ Bolsa Escola is a public cash transfer program conditional on children's school attendance.
} 
We claim that the seemingly conflicting results from the empirical literature are entirely consistent with economic theory, once one realizes that different types of shocks to family income - or different types of experiments - bring together different combinations of income and substitution effects. Income changes that are mostly associated with changes in households' full income should represent either pure income effects or situations where income effects tend to be relatively more important, and therefore should increase the demand for schooling and reduce child labor. On the other hand, short term fluctuations in wages, income, or economic growth particularly when analyzed as deviations from a given secular trend - should be mostly associated with increases in the opportunity cost of children's time, given an expected present value of full income. Therefore, these changes should isolate the substitution effect and bring together increased child labor and reduced schooling.

In order to clarify how these different margins affect household choices regarding child labor and schooling, we develop a very simple model that captures the main empirical implications of the theoretical literature (Baland and Robinson, 2000, Basu and Van, 1998, and Dessy, 2000). In addition to making explicit the argument developed in the previous paragraph, the model leads to an empirical specification from a set of structural equations that can be immediately taken to the data. The vast majority of empirical work analyzes the child labor and schooling decisions as separate, discrete choices. ${ }^{4}$ However, in our model, child labor and schooling are not mutually exclusive, and the response of households to changes in income may vary with their level of consumption. The theory leads to a formulation where, in order to account for all the relevant dimensions of the environment faced by families, child labor and schooling decisions are characterized as a generalized ordered discrete choice problem. This formulation highlights both the set of alternatives available to families (work only, schooling and work, and schooling only) and the fact that families choosing each one of these different alternatives may respond differently to marginal changes in exogenous variables. The theory also highlights the necessity to distinguish between changes in family full income and children's wages for the different dimensions of the income and substitution effects to be adequately identified. ${ }^{5}$

In order to implement the empirical specification, and given the limitations of the data typically available, we exploit shocks to coffee and total agricultural production in Brazil as

\footnotetext{
${ }_{5}^{4}$ Exceptions are Levison et al (2000) and Bourguignon et al (2003), who estimate multinomial logits.

${ }^{5}$ In the micro-simulations performed by Bourguignon et al (2003), the conditional cash transfer program analyzed has potentially both income and substitution effects (by reducing the opportunity cost of schooling and, simultaneously, increasing family income). But the authors do not address this issue explicitly, nor try to separately identify these two components.
} 
exogenous variation in the demand for unskilled labor. We concentrate the analysis on Brazil's coffee producing regions and rural areas, between 1993 and 2003, and use household data from the Brazilian Household Survey (Pesquisa Nacional por Amostras de Domicílio - PNAD) and agricultural production data from the Brazilian Census Bureau (Instituto Brasileiro de Geografia e Estatística - IBGE). Controlling for family income and wealth, and for secular trends in income, we are able to distinguish between the effects of family income and increased demand for child labor (due to shocks to local economic activity). We find that, conditional on family socioeconomic status and wealth, and on long-term growth, exogenous shocks to local economic activity are associated with increased child labor and reduced schooling. Nevertheless, family socioeconomic status and wealth - as measured by hourly wage and job tenure of the head of the household, non-labor income, and ownership of various durable goods - are associated with reduced child labor and increased schooling.

Additionally, in conducting various robustness checks, we identify the role of a series of demographic correlates of child labor. Older children are more likely to work, while children with higher educational attainment for a given age are more likely to be in school. Girls are more likely to be in school and not working, while children living in rural areas are more likely to be working and not in school. Conditional on household wealth and socioeconomic status, children living in households with many children are more likely to work and less likely to be in school.

The remainder of the paper is organized as follows. In section 2, we develop a theoretical model of child labor and schooling, and derive its empirical specification. In section 3, we describe the data used in the analysis and discuss the empirical implementation of the model. In section 4, we present and discuss the results. Finally, section 5 concludes the paper.

\section{A Simple Model of Child Labor and Schooling}

\subsection{The Household Problem}

This section develops a simple model of the joint household decision regarding child labor and schooling. We concentrate on a simplified version of the household problem in order to obtain a model that can be immediately taken to the data, and to highlight the dimensions that are added by considering the joint decision. Though formally different, our model shares the same basic properties of the theory proposed by Basu and Van (1998). From an empirical perspective, our theory shows that, depending on the household's choice of child labor and schooling, it may respond differently to changes in the economic environment. This partly explains some of the seemingly contradictory results obtained in the previous empirical literature. 
Consider an economy where parents make all the relevant decisions. Since we want to emphasize the different roles of family vis-à-vis child's income in determining the labor supply and schooling decision, we assume that each household has only one parent and one child. The household derives utility from consumption and from the human capital of the child according to the utility function

$U(c, h)=\frac{c^{\sigma}}{\sigma}+\beta h$

where $c$ is household consumption, $h$ is the human capital of the child, and $\beta$ and $\sigma$ are constant parameters, with $0<\sigma<1$ and $\beta>0$.

Consumption goods are purchased with income from adult and child labor. Assume that parents participate fully in the labor market, so that their labor supply is fixed at the total amount of labor time available $\left(t_{p}\right)$. Consumption satisfies the following budget constraint:

$c \leq w_{c} l_{c}+w_{p} t_{p}$

where $w_{c}$ is the child wage, $w_{p}$ is the adult wage, ${ }^{6}$ and $l_{c}$ is the labor supply of the child.

The child's time has to be allocated between work and investments in human capital according to

$l_{c}+e_{c}=t_{c}$

where $e_{c}$ is the time spent on investments in human capital by the child, and $t_{c}$ is the total amount of time available for the child.

We abstract from the material costs of investments in education and assume that human capital is produced only with the time of the child, according to the technology $h=\alpha e_{c} \exp (v)$, where $\alpha$ is a technological constant and $v$ is an individual specific factor. Several family and individual characteristics - ranging from education of parents to idiosyncratic ability or luck may affect the productivity of investments in human capital. These are summarized in the term $v$.

\footnotetext{
${ }^{6}$ In principle, the adult wage depends on the level of human capital previously accumulated by the parent. We do not deal with this explicitly here, but it is the motivation behind the fact that the household attaches positive value to the human capital of the child (human capital is translated into higher future earnings).
} 
We model $v$ as being a linear function of a vector of demographic characteristics of the household $(x)$ and a random term $(\varepsilon)$, such that $v=\gamma^{\prime} x+\varepsilon$.

Writing down the full income constraint and substituting for $h$ in the utility function, the household problem can be stated as

$$
\max _{\left\{c, e_{c}\right\}}\left\{\frac{c^{\sigma}}{\sigma}+\beta \alpha e_{c} \exp (v)\right\}
$$

subject to $c+w_{c} e_{c} \leq w_{c} t_{c}+w_{p} t_{p}$.

This very simple framework displays the same basic empirical implications stressed in the original work of Basu and Van (1998). First, both children and adults can earn wages, so that their labor supplies are seen as substitutes from the perspective of generating income for the household (Substitution Axiom). Second, since preferences are quasi-linear in the human capital of the child, household demand for child's education respects what Basu and Van (1998) call the Luxury Axiom. In other words, for sufficiently low family consumption, the marginal utility of consumption is so high that the family allocates all of the child's time to the labor market. As family consumption grows and the marginal utility of consumption declines, the family eventually starts investing some of the child's time in acquiring education and, from this point on, additional family resources are devoted entirely to investments in the child's human capital. ${ }^{7}$ This remains true until the child dedicates her time fully to schooling, when again additional resources start being devoted to household consumption. This is precisely the pattern that Basu and Van (1998) try to generate with their model. The only difference is that the minimal level of consumption, which in their case is given by what they call the subsistence level, here depends also on the wage that the child faces on the market. In other words, when deciding what is minimally acceptable to the family, parents are actually comparing the future benefits from the child's education with the current market value of the child's labor. In addition, our model leads to an empirical specification that can be immediately taken to the data.

Under these circumstances, the static nature of the model can be reinterpreted as describing an environment where families face credit constraints in their decisions about consumption and investments in children. In this specific context, credit constrains can take on

\footnotetext{
${ }^{7}$ If the child's time was not an input in the production of human capital, all additional resources would indefinitely be invested in the human capital of the child, and household consumption would never grow beyond what Basu and Van (1998) call the subsistence level. But since child's time is needed to produce human capital, this model generates exactly the same pattern discussed by these authors.
} 
two forms: the usual lack of access to capital markets, and, in addition, the inability of agents to transfer debt to future generations, even with access to capital markets. In principle, with agents having access to capital markets, the transfer of debt across generations could be a way of taking advantage of higher returns to investments in human capital of children (as discussed at length in Becker, 1981). But this possibility is typically not allowed in modern societies, therefore introducing an intrinsic dimension of credit constraint in intergenerational problems. Since both types of credit constraints are important issues for poor families in developing countries, and these are the relevant families when discussing the phenomenon of child labor, we keep this interpretation of the model throughout the paper.

The family decision regarding child labor and schooling becomes clear from the first order conditions of the problem. Defining $\lambda$ as the multiplier on the full-income constraint, first order conditions for $c$ and $e_{c}$ are, respectively,

$$
\begin{aligned}
& c^{\sigma-1}=\lambda, \text { and } \\
& \alpha \beta \exp (v) \stackrel{<}{=} \lambda w_{c} \\
& \alpha
\end{aligned}
$$

with the inequality holding as $<$ when $e_{c}=0$, as $=$ when $0<e_{c}<t_{c}$, and as $>$ when $e_{c}=t_{c}$. Given the utility function, consumption will always be strictly positive as long as family income is strictly positive.

The second first order condition characterizes the household decision regarding child labor and schooling. If $\alpha \beta \exp (v)<c^{\sigma-1} w_{c}$, the marginal gain from investments in human capital is lower than the marginal value of child labor, so the child works and does not go to school. If $\alpha \beta \exp (v)=c^{\sigma-1} w_{c}$, the marginal value of one unit of time invested in human capital equals the marginal value of one unit of time supplied in the labor market, so the child shares her time between work and schooling. If $\alpha \beta \exp (v)>c^{\sigma-1} w_{c}$, the marginal value of one unit of time invested in human capital is higher, so the child spends all her time studying. ${ }^{8}$

\footnotetext{
${ }^{8}$ A fully recursive model, where parents utility depended on the child's utility, which in turn would depend on wages, would lead to a similar characterization of the three alternative choices available to families. The only difference in this case would be that the term $c^{\sigma-1}$ would be replaced by the inverse of the growth rate of consumption across generations, and another constant term $\left(t_{p}\right)$ would appear multiplying the left-hand side of the expression. Still, the basic trade-off would be between the future welfare of the child (in our model represented directly via a reduced form by $h$ ) and the current welfare of the family. We keep the formulation in the text because it is simpler and leads in a more direct way to our empirical specification. In the case of the fully recursive model, we would simply need to reinterpret the variable $s_{p}$ defined later on in the text.
} 
Our goal is to characterize the discrete choice of the household between these three states: child labor and no schooling, child labor and schooling, and no child labor and schooling. As will be clear soon, the effect of changes in wealth and wages on family decisions is different according to the situation in which the child is found.

\subsection{Choices of Child Labor and Schooling}

\section{$1^{\text {st }}$ Case: Work and No Schooling}

This choice is characterized by the inequality $\alpha \beta \exp (v)<c^{\sigma-1} w_{c}$. In this case, all the child's time is used as labor supply, such that $l_{c}=t_{c}$ and $e_{c}=0$. Families in this situation already send their children to work, and, for small changes in the economy, will never switch to a situation where the children go to school and are entirely out of the labor market. What they contemplate is the possibility of starting to invest part of the children's time on schooling. From the budget constraint, consumption is given by $c=w_{c} t_{c}+w_{p} t_{p}$, so that $\alpha \beta \exp (v)<\left(w_{c} t_{c}+w_{p} t_{p}\right)^{\sigma-}$ ${ }^{1} w_{c}$. Substituting the expression for $v$ and using natural logarithms:

$\varepsilon<\ln (1 / \alpha \beta)+\ln w_{c}+(\sigma-1) \ln \left(w_{c} t_{c}+w_{p} t_{p}\right)-\gamma^{\prime} x$

This formulation decomposes the income and substitution effects in the household decision. The $\ln w_{c}$ term represents the pure substitution effect, while family full-income $\left(\ln \left(w_{c} t_{c}\right.\right.$ $\left.+w_{p} t_{p}\right)$ ) represents the pure income effect. For constant family income, a higher wage for the child is associated with a higher opportunity cost of schooling and, therefore, a higher probability that the child will work and not go to school. For constant wage of the child, higher family income is associated with a lower probability that the child will work and not go to school. An uncompensated change in $w_{c}$, on the other hand, does not have an unequivocal effect. This change brings together both income and substitution effects, and the final result depends on their relative strength.

$2^{\text {nd }}$ Case: Schooling and No Work

This choice is characterized by the inequality $\alpha \beta \exp (v)>c^{\sigma-1} w_{c}$. In this case, all the child's time is used on investments in human capital, so that $l_{c}=0$ and $e_{c}=t_{c}$. For small changes in the economy, families in this situation contemplate whether to start sending the children parttime to the labor market. From the budget constraint, consumption is given by $c=w_{p} t_{p}$, so that

the inequality can be written as $\alpha \beta \exp (v)>w_{c}\left(w_{p} t_{p}\right)^{\sigma-1}$. Substituting the expression for $v$ and using natural logarithms: 
$\varepsilon \geq(1 / \alpha \beta)+\ln w_{c}+(\sigma-1) \ln \left(w_{p} t_{p}\right)-\gamma^{\prime} x$.

In this case, the child does not work, so the income effect is captured only by the fullincome of parents $\left(\ln \left(w_{p} t_{p}\right)\right)$. Marginal changes in children's wages do not affect the consumption of the family and, therefore, have no income effect. But they do affect the opportunity cost of investments in human capital. For these families, increases in the wage of children increase the opportunity cost of schooling and unequivocally raise the probability that the children work and go to school, instead of going to school only. On the other hand, for given children's wages, increases in parents' income raise the probability that children go to school only, instead of working and going to school.

$3^{\text {rd }}$ Case: Work and Schooling

This is the intermediary case, with $\alpha \beta \exp (v)=c^{\sigma-l} w_{c}$. In this situation, we have $l_{c}>0$ and $e_{c}>0$. In words, the children share their time between work and schooling. From the first order conditions, consumption is given by $c=\left[\alpha \beta \exp (v) / w_{c}\right]^{1 /(\sigma-1)}$. Using the expression for $v$, this situation is characterized by the following inequalities

$$
\begin{aligned}
\ln (1 / \alpha \beta)+\ln w_{c}+(\sigma-1) \ln \left(w_{c} t_{c}+w_{p} t_{p}\right)-\gamma^{\prime} x & \leq \varepsilon \\
& \leq \ln (1 / \alpha \beta)+\ln w_{c}+(\sigma-1) \ln \left(w_{p} t_{p}\right)-\gamma^{\prime} x .
\end{aligned}
$$

\subsection{Empirical Specification}

The household faces a discrete choice with three possible options in relation to the child: work and no schooling, work and schooling, and schooling and no work. Define the discrete variable $J$ indicating the household choice as 0,1 , and 2, accordingly. The household decision can be summarized as follows:

$$
J=\left\{\begin{array}{c}
0, \text { if } \varepsilon<1 / \alpha \beta+\ln w_{c}+(\sigma-1) \ln \left(w_{p} t_{p}+w_{c} t_{c}\right)-\gamma^{\prime} x, \\
1, \text { if } 1 / \alpha \beta+\ln w_{c}+(\sigma-1) \ln \left(w_{p} t_{p}+w_{c} t_{c}\right)-\gamma^{\prime} x \leq \varepsilon \\
<1 / \alpha \beta+\ln w_{c}+(\sigma-1) \ln \left(w_{p} t_{p}\right)-\gamma^{\prime} x, \\
2, \text { if } \varepsilon \geq 1 / \alpha \beta+\ln w_{c}+(\sigma-1) \ln \left(w_{p} t_{p}\right)-\gamma^{\prime} x .
\end{array}\right.
$$

This is a generalized ordered discrete choice model. If the random term $\varepsilon$ is low enough, the household chooses state 0 ; if it has intermediary values, the household chooses state 1 ; and if 
it has sufficiently high values, the household chooses state 2. The difference from standard ordered models lies in the fact that the threshold point in this case is not constant. The threshold here is given by the explanatory variables, implicit in the difference between $\ln \left(w_{p} t_{p}+w_{c} t_{c}\right)$ and $\ln \left(w_{p} t_{p}\right)$, which varies across households.

Now index observations related to the $i^{\text {th }}$ child by the subscript $i$, with $i \in I=\{1, \ldots, n\}$, where $n$ is the number of observations in the sample. Assume that $\varepsilon$ is randomly distributed with distribution function $F$ (.). Additionally, define $Z_{i j}=1$ if child $i$ is in state $j$, with $Z_{i j}=0$ otherwise, where $j \in J=\{0,1,2\}$. The likelihood function for the discrete choice problem discussed above is given by

$$
L=\prod_{i=1}^{n}\left\{\begin{array}{l}
{\left[F\left(1 / \alpha \beta+\ln w_{c i}+(\sigma-1) \ln \left(w_{p i} t_{p}+w_{c i} t_{c}\right)-\gamma^{\prime} x_{i}\right)\right] z^{z_{i 0}} \times} \\
{\left[\begin{array}{c}
F\left(1 / \alpha \beta+\ln w_{c i}+(\sigma-1) \ln \left(w_{p i} t_{p}\right)-\gamma^{\prime} x_{i}\right)- \\
-F\left(1 / \alpha \beta+\ln w_{c i}+(\sigma-1) \ln \left(w_{p i} t_{p}+w_{c i} t_{c}\right)-\gamma^{\prime} x_{i}\right)
\end{array}\right]^{z_{i 1}} \times} \\
{\left[1-F\left(1 / \alpha \beta+\ln w_{c i}+(\sigma-1) \ln \left(w_{p i} t_{p}\right)-\gamma^{\prime} x_{i}\right)\right]^{z_{i 2}} .}
\end{array}\right\}
$$

There are two main problems with this formulation. First, for a significant fraction of children, we do not observe market wages, and market wages may be endogenous to child labor decisions in previous periods. And second, we do not observe full family income, which becomes an even more difficult problem because of the previous issue.

In relation to child wages, we opt to use two alternative proxies for the level of demand for child labor at the municipality where the child lives. This allows us to use all the children in the sample, including the large number of those who do not work. The specific proxies that will be used are based on the value of local agricultural production (coffee and overall agricultural production), and will be discussed in detail later on. The basic idea is that these variables are correlated with the local demand for unskilled labor, and at the same time have some degree of exogenous variation due to the inherent uncertainty associated with climatic conditions and agricultural production.

In relation to the second problem, we adopt the following strategy. The logarithm of household full-income can be rewritten as $\ln \left(w_{c i} t_{c}+w_{p i} t_{p}\right)=\ln w_{p i}+\ln t_{p}-\ln s_{p i}$, where $s_{p i}=$ $t_{p} w_{p i} /\left(t_{p} w_{p i}+t_{c} w_{c i}\right)$. The term $s_{p i}$ gives the share of the family's full-income that comes from parents, or, alternatively, the relative importance of the child in terms of the income generating power of the household. Notice that it refers to full-income, so that, given the educational level of parents and the market wages faced by parents and children, it does not depend on household 
decisions at that specific point in time. It will typically depend on family characteristics such as educational attainment and age of the different members, gender of the child, composition of the household, wealth, etc. Since $0 \leq s_{p i} \leq 1$, we have $\ln s_{p i} \leq 0$, and the discrete choice problem discussed before can be represented by

$$
J=\left\{\begin{array}{l}
0, \text { if } \varepsilon_{i}<\alpha^{*}+\ln w_{c i}+(\sigma-1) \ln w_{p i}-\gamma^{\prime} x_{i}-(\sigma-1) \ln s_{p i}, \\
1, \text { if } \alpha^{*}+\ln w_{c i}+(\sigma-1) \ln w_{p i}-\gamma^{\prime} x_{i}-(\sigma-1) \ln s_{p i} \leq \varepsilon_{i}<\alpha^{*}+\ln w_{c i}+(\sigma-1) \ln w_{p i}-\gamma^{\prime} x_{i} \\
2, \text { if } \varepsilon_{i} \geq \alpha^{*}+\ln w_{c i}+(\sigma-1) \ln w_{p i}-\gamma^{\prime} x_{i}
\end{array}\right.
$$

where $\alpha^{*}=\ln \left(t_{p}{ }^{\sigma-1} / \alpha \beta\right)$. Given some distribution function $F($.$) , the likelihood function for this$ problem is analogous to the one in (10).

As mentioned before, the term $s_{p i}$ will typically depend on household characteristics capturing the wealth and income generating power of parents, as well as the potential market wage of children. Assume that we can write $s_{p i}$ as a function of a set of demographic characteristics $z_{i}$, as in $\ln s_{p i}=\theta^{\prime} z_{i}$. In principle, $z_{i}$ and $x_{i}$ can contain different elements or can be the same vector. If they contain only different elements, the variables in $z_{i}$ will be responsible for determining the shift in the threshold as family characteristics change. Alternatively, if $z_{i}$ and $x_{i}$ are the same vectors, the threshold will be identified by allowing the coefficients on the variables in $x_{i}$ to vary across the limits of the different categories. In the remainder of the paper, we assume that $\ln s_{p i}=\theta^{\prime} z_{i}$. We save the discussion on the components of the vectors $x_{i}$ and $z_{i}$ for the next section.

Other empirical issues arise because of the simplifying assumptions of the theoretical model (e.g., households with only one child, parents employed full-time, etc.). These will be dealt with in the empirical section, through the choice of sample and robustness checks performed after the initial estimation.

\section{Data and Variables}

\subsection{Data Sources}

The data we use come from three different sources. All household level variables are constructed from nine rounds of the Brazilian household survey (PNAD), which contains information on characteristics of all household members. The PNAD is conducted nationally throughout Brazil during the month of September of each year. We restrict the analysis to the 
period between 1993 and 2003, for which consistent sampling methodologies and questionnaires were maintained. ${ }^{9}$

The second source of data is the municipality-level surveys of agricultural production administered each year by the Brazilian Census Bureau (Instituto Brasileiro de Geografia e Estatística - IBGE), which we use to construct variables measuring the value of coffee production per capita, as well as the value of overall agricultural production per capita. This survey provides annual data of area planted, area harvested, quantity produced, and values of most agricultural goods in Brazil. We also use municipality level GDP and population data from the Brazilian Institute of Applied Economic Research (Instituto de Pesquisa Econômica Aplicada - IPEA) and from IBGE.

\subsection{Variables and Sample Selection}

Our dependent variable follows the empirical specification laid out by equation (11) and reflects the child's school-work decision ordered according to what may be regarded as increasingly "better" outcomes in terms of allocation of time. ${ }^{10}$ It is equal to 0 if the child works exclusively, 1 if the child works and goes to school, and 2 if she only goes to school. The variable is constructed based on two questions asking whether the child worked last week or at any point during the past 12 months, and whether she is currently enrolled in school. ${ }^{11}$ Our definition of child work is not restrictive and includes children who worked at any point during the previous 12 months.

Three sets of independent variables constitute our main interest. First, we need variables that would capture wage variations for both parents $\left(w_{p i}\right)$ and children $\left(w_{c i}\right)$. Second, we need a set of variables capturing the return to schooling for each particular child $\left(x_{i}\right)$. And, finally, we need a set of variables indicating the relative importance of the child's income in terms of the full potential income of the household $\left(z_{i}\right)$, or, in a more general setting, in terms of the household's wealth.

\footnotetext{
${ }^{9}$ We include the following years: 1993, 1995-1999, 2001-2003. In 1994 and 2000 PNAD was not conducted.

${ }^{10}$ This statement is not entirely precise, since a family can always be made better off with the child working (in comparison with the child not working), as long as the child's wage is sufficiently high. Nevertheless, these choices are indeed ordered from the perspective of the family choice (the statement would be precisely correct if we thought in terms of changes in the wage of the head of the household).

${ }^{11}$ A fourth outcome would be if the child responded no to both questions, which could be interpreted as dedicating time exclusively to leisure. However, we believe that children are not likely to be completely idle, so that this response probably hides some type of work - domestic or in the market - or a transitory state. Rather than reassigning this outcome to one of the other groups, we do not include it in the empirical analysis; less than 5 and 4 percent of children in the rural and coffee samples, respectively, fall into this category.
} 


\section{Wages and Proxies for the Demand for Child Labor}

For the first set of variables we use as parent's hourly wage the head of the household hourly wage, constructed from data on labor earnings and hours worked. In order to minimize the problem of interaction between child labor and labor supply decisions of adults, and to bring the sample closer to our theoretical model, we restrict the analysis to observations where the head of the household is employed full-time. Later on we also introduce additional variables to control for the interaction between labor supply of children and labor supply of other adults in the household. We define working full-time for an adult as working al least 30 hours per week. Then we define the head of the household as the spouse, in the main family unit of the household, who has the highest hourly wage (in case both spouses work fulltime). ${ }^{12}$ We also restrict the sample to children aged 10 to 14, to heads of the household between 18 and 65 years of age, and to children who are relatives of the head of the household, in order to concentrate the analysis on a more homogeneous group and to avoid including children who are treated differently within the family unit. ${ }^{13}$

As mentioned in the previous section, we do not observe child wages for all children, so we need to use proxies for the level of demand for child labor. In this respect, we use two different strategies, each of them generating a different sample. In the first strategy (coffee production sample) we use the value of coffee production per capita (in logarithms) as a proxy for the level of economic activity, which may affect the opportunity cost of children's time. In the second one (agricultural production sample), we use the value of agricultural production per capita (in logarithms). Both measures are constructed at the level of the municipality where the child lives (see full description below).

We see these two measures as proxies for the demand for low-skilled labor, for which child labor could potentially be a substitute. In municipalities where coffee or agriculture are economically important, the value of coffee production or the value of agricultural production are important indicators of local economic activity, and at the same time maintain a certain level of exogeneity, given the uncertainties generally associated with climatic conditions and agricultural production. Similar identification strategies were used by Schultz (1985), where commodity prices served as instruments for the opportunity cost of women's time, by Black et al

\footnotetext{
${ }^{12}$ PNAD classifies the head of the household according to self-reporting. In the samples that we use, at least 84 percent of the self-reported heads of the household are also the spouses with the highest wage. In the rest of the paper all characteristics of the head of the household use our definition (based on the highest hourly wage among spouses working full-time).

${ }^{13}$ Relatives are sons and daughters, and other relatives (including grandchildren and stepchildren).
} 
(2003), where the price of coal was used as an instrument for men's wages, and by Kruger (2006a and 2006b), where coffee production was used as a proxy of the value of children's time.

In the case of coffee production, we concentrate the analysis on municipalities where coffee is an important economic activity. In this case, we see increased demand for child labor not as being necessarily linked to harvesting or actual agricultural production. Where coffee is an important activity, increased production may increase demand directly through demand for work in agriculture, but also indirectly, through increased demand for labor in the transportation, processing, and packaging of coffee, as well as in other auxiliary and satellite activities affected by coffee cycles. So in order to concentrate the analysis on localities where coffee production is indeed important, we restrict this sample to municipalities in the top $60 \%$ of coffee producing municipalities. This selection criterion means that we include municipalities where the average share of coffee production in total GDP between 1996 and 2002 - the years for which we have both series - was at least 0.1 percent. In addition, to concentrate on localities where this shock was indeed relevant for most of the population, we selected municipalities with total population equal to less than 100,000 inhabitants.

For the agricultural production sample, we have a slightly different type of motivation in mind. In this case, we are indeed thinking about increased demand for labor in agriculture (harvesting, plowing, etc.), maybe due to unusually good climatic conditions or exceptionally high commodity prices. In this case, we have an easier way to define the relevant sample. The PNAD questionnaire already identifies households that are located in rural areas. So we restrict the sample to rural households according to this variable, and use the value of total agricultural production per capita as a proxy for the demand for child labor.

The incidence of the three possible outcomes for each year of our data is presented in Table 1 separately for each of the two samples. Figures 1 and 2 also present the distribution of weekly hours of work for children included in either of the two samples. As can be seen from the table, the school-work decisions follow similar trends in both samples. Work only exhibits a sharp declining trend with the incidence falling from more than $10 \%$ to less than $2 \%$ between 1993 and 2003 (in both samples). Work and school shows a clear declining trend in the agricultural sample (23\% in 1993 and 11\% in 2003), but just a slightly declining trend in the coffee production sample (37\% in 1993 and 33\% in 2003). Finally, the school only outcome exhibits an increasing trend in both samples, although the increase is stronger in the coffee production sample. From Figures 1 and 2, one can see that roughly 85 percent of working 
children in our samples worked at least 10 hours per week at some point during the previous 12 months, and at least 75 percent worked more than 15 hours per week.

Table 2 presents the value of coffee and agricultural production per capita for municipalities included in the samples using the restriction criteria described in the last page. The value of coffee production per capita increases steadily between 1993 and 1999. In 2001, the value of production collapses - along with the international and domestic prices of coffee - to 55 percent of the 1999 value and below the level observed at the beginning of the period. Afterwards, production experiences a recovery, but still remains below the 1995 levels. Agricultural production declines in the first half of the 1990's and experiences a recovery in the second half of the decade. As with coffee, agricultural production reaches the minimum value of the sample in 2001, but then it experiences a sustained recovery that culminates in 2003, when we observe the maximum value for the period analyzed. Our samples include typically 143 municipalities in the case of coffee production, and 545 municipalities in the case of agricultural production.

\section{Other Independent Variables and Additional Controls}

In relation to the variables affecting the return to schooling $\left(x_{i}\right)$, we include years of schooling, gender, race, and the age of the child, along with whether the household lives in a rural area (for the coffee production sample). We also include the age of the head of the household, years of education of the head of the household, and whether the head the household is female. The age, gender and race of the child, previous investments in human capital, and rural location may all affect the marginal gain from additional years of education. The age and education of the household head, and whether the household is headed by a woman, may reflect family characteristics that can be seen as direct inputs into the human capital production function and, because of that, may affect the productivity of investments in education.

The importance of the child's earning potential in relation to the household's full income $\left(z_{i}\right)$ depends, to a great extent, on a set of variables very similar to those determining the return to schooling of the child. In this respect, we want variables capturing the child's earning potential and also indicators of the household's full income (or wealth). The child's age, educational attainment, and the location of the household in a rural area may all affect her earning potential. Parent's tenure in the current job, other income of the household, and variables related to household infrastructure are all closely related to the household's full income and wealth. In

relation to household infrastructure, we consider variables that may indicate the socioeconomic 
status of the family, such as the number of bedrooms per person, the availability of electricity and the possession of a telephone line (fixed), a television set, a refrigerator, and a washing machine. These are durable goods typically ordered in terms of family choices, so that they are closer to indicating differences in socioeconomic status, rather than differences in tastes.

Variables included only in $x_{i}$ will appear with the same coefficient in the first and second transition equations shown in expression (11). Variables included in both $x_{i}$ and $z_{i}$ will also appear in both equations, but with different coefficients in each one. Finally, variables included in $z_{i}$, but not in $x_{i}$, will appear only in the first equation, denoting the transition between state 0 (child labor and no schooling) and state 1 (child labor and schooling).

One important concern is related to factors not included in the discussion above, but that may be correlated with the explanatory variables and with household decisions. To account for the role of housework, intra-household substitution of labor, and dilution of family resources across different children, we control for: the presence of other children in the household, identified by particular age group ( 5 and below, between 6 and 9, and between 15 and 18); the total number of siblings; the presence of a person above 60 years of age in the household; whether both parents work; and whether the head of the household is a single parent. To account for territorial variables that may be correlated to coffee and agricultural production, and to the incidence of child labor, we use state fixed-effects in all regressions. Also, in order to allow for further variations along this dimension, our robustness checks include as additional controls medium-region fixed-effects (geographic units smaller than states that aggregate contiguous municipalities), municipality characteristics such as GDP per capita and population, and statespecific time dummies. Since these variables are not directly mapped into our simple theoretical model, we let them enter in both $x_{i}$ and $z_{i}$ in the empirical specification.

We also test the robustness of the results to several different restrictions on the sample and to alternative definitions of the dependent variable. Detailed discussion on these issues is saved until the next section. Table 3 presents summary statistics for all explanatory variables discussed here.

\section{Results}

Drawing on the theoretical section, we assume that the error term $\varepsilon$ follows a logistic distribution, so that the choice problem described in equation (11) can be represented by a 
generalized ordered logit model. ${ }^{14}$ Again, the dependent variable takes on the following three values: 0 if the child did not attend school and worked at any time during the previous 12 months, 1 if the child worked and went to school simultaneously, and 2 if the child attended school and did not work during the previous year. The generalized aspect of the model means that the proportional odds assumption is not maintained, so that thresholds between the three outcomes may vary according to the family's characteristics.

\section{Baseline Results}

Table 4 presents the main results of our estimation. The first two columns contain the estimated parameters for the two transition equations in the coffee sample, under our simplest specification. This specification includes the value of coffee production per capita and the wage of the head of the household (both constrained to be the same across the two equations), and child and household characteristics, which are assumed to be part of $x_{i}$ and $z_{i}$, so that they appear in both transition equations, but with different coefficients in each one. Implicitly, we are assuming that variables affecting the child's return to schooling also affect the relative importance of her income to the household, so that all variables included in $x_{i}$ are also considered part of $z_{i}$. In the third and forth columns, we present the results for the coffee sample including the socioeconomic variables as additional controls. ${ }^{15}$ As these variables are related to the importance of the child's income to the household, but not necessarily to the child's return to schooling, they are assumed to be part of $z_{i}$, but not of $x_{i}$, and therefore appear only in the first transition equation and are excluded from the second one. This is our baseline specification, which will guide most of the discussion and subsequent robustness tests. The remaining columns in the table present analogous results for the agricultural production sample, where the value of coffee production per capita is replaced by the value of agricultural production per capita.

The coefficients presented in Table 4 refer to the effects of the explanatory variables on the likelihood of working only compared to going to school and working (columns 1, 3, 5 and 7), and on the likelihood of going to school and working compared to going to school only (columns 2, 4, 6 and 8). The estimated coefficients measure the effect of the independent variables on the likelihood of higher-valued outcomes. So a positive and significant coefficient on the first transition equation means that increases in the independent variable are associated, for families

\footnotetext{
${ }^{14}$ We assume that the error term follows a logistic rather than a normal distribution because the estimation of generalized ordered probit models is particularly cumbersome from the numerical perspective. Our estimation was implemented using the commands and guidelines discussed in Williams (2006).

${ }^{15}$ These coefficients are omitted from the table for clarity of exposition but are available upon request.
} 
within that margin of choice, with a higher likelihood that the child works and goes to school, instead of only working. Similarly, a positive and significant coefficient in the second transition equation means that increases in the independent variable are associated, for families within that margin of choice, with a higher probability that the child only goes to school, instead of working and going to school simultaneously.

Results are very similar across the different specifications presented in the table. Also, qualitative results are very similar when comparing the coffee production and the agricultural production samples. Conditional on the hourly wage of the head of the household, higher values of coffee or agricultural production per capita are associated with worse outcomes for children. At the same time, conditional on the value of coffee or agricultural production, higher hourly wages for the head of the household are associated with better outcomes for children. This reveals that, conditioning on the hourly wage of the head of the household, on determinants of the return to schooling and on the relative importance of the child's income for the family, as well as period-specific dummies, the value of coffee or agricultural production per capita highlights the substitution effect from increased economic activity. ${ }^{16}$ Conditional on all these factors, exogenous increases in economic activity are associated with increased opportunity cost of children's time and, therefore, increased child labor and reduced school attendance.

Most of the control variables also have the expected effects. Children who are older or live in rural areas (for the coffee production sample) are more likely to be working and less likely to be in school, while, conditional on age, children with more years of schooling are more likely to stay in school. Also, children with more educated parents are more likely to be in school and not to work, while children in families with better socioeconomic characteristics (not shown in the table) are more likely to stay in school. ${ }^{17}$

In order to analyze the effect of the exogenous variable on the probability of occurrence of the three alternative outcomes, we calculate the marginal effects for both the coffee and agricultural production samples, using the most complete specification presented in Table 4 (columns 3-4 and 7-8). Results are found in Table 5.

Since coffee production, agricultural production, and the adult wage variables are measured in natural logarithms, we can interpret the marginal effects as the impact of a 100

\footnotetext{
${ }^{16}$ In reality, increases in demand for child labor also always bring together a bit of income and substitution effects. But the results show that our strategy, and the controls that we include in the estimation, tend to isolate the substitution effect. This result is consistent with that in Kruger (2006b).

17 Among the socioeconomic characteristics included, number of bedrooms per capita, tenure of the head of the household on the current job, and the presence of a telephone and a fridge in the household are the variables more closely related to the probability that the child attends school.
} 
percent increase in the independent variables on the probability that each outcome occurs. For example, in the coffee production sample, a 100 percent increase in the value of coffee production leads to an increase of 0.04 percentage points in the proportion of children working only (column 1), to an increase of 0.52 percentage points in the proportion of children working and going to school (column 2), and to a reduction of 0.56 percentage points in the proportion of children only going to school (column 3). In the agricultural production sample, a 100 percent increase in the value of coffee production leads to an increase of 0.20 percentage points in the proportion of children working only (column 4), to an increase of 1.30 percentage points in the proportion of children working and going to school (column 5), and to a reduction of 1.50 percentage points in the proportion of children only going to school (column 6).

To get a sense of the magnitude of these changes, we divide the marginal effect by the observed probability of each outcome, which is reported at the bottom of Table 5. For the coffee production sample, the observed changes correspond to increases of 1 percent in the probability of work only and 3.1 percent in the probability of work and schooling, and to a reduction of 0.70 percent in the probability of schooling only. For the agricultural production sample, they correspond to increases of 2.9 and 3.9 percent in the probabilities of, respectively, work only and work and schooling, and to a reduction of 2.6 percent in the probability of schooling only.

In relation to the wage of the head of the household, in the coffee production sample, a 100 percent increase is associate with a reduction of 0.26 percentage points in the fraction of children only working, a reduction of 3.4 percentage points in the fraction of children working and going to school, and an increase of 3.7 percentage points in the fraction of children only going to school. In terms of the relative sizes of the different groups, these magnitudes represent the following proportional changes: a reduction of 6.2 percent in the probability of work only, a reduction of 20.2 percent in the probability of work and schooling, and an increase of 4.7 percent in the probability of schooling only. In the agricultural production sample, an increase of 100 percent in the wage of the head of the household is associated with a reduction of 0.64 percentage points in the fraction of children only working, a reduction of 4.3 percentage points in the fraction of children working and going to school, and an increase of 4.9 percentage points in the fraction of children only going to school. In terms of the relative sizes of the different groups, these magnitudes represent the following proportional changes: a reduction of 9.4 percent in the probability of work only, a reduction of 12.0 percent in the probability of work and schooling, and an increase of 8.5 percent in the probability of schooling only. 
Overall, the responses of households to changes in economic activity and overall wealth follow the pattern predicted by our theory. The shocks to local economic activity, once we control for household characteristics, socioeconomic status, time trends, and state-specific factors, do seem to isolate mostly the substitution effect from the increased demand for child labor in the short-run. On the other hand, conditional on all other control variable, socioeconomic status and the wage of the head of the household seem to isolate the income effect, leading to better outcomes in terms of the allocation of time of children. The conflicting effects found in previous papers are obtained here as different dimensions of the response of families to increases in income and in the level of economic activity. Here, these results are entirely consistent with economic theory and with the rational behavior of households.

\section{Robustness Checks}

In order to test the robustness of the results to different alternative hypotheses and to address some issues not explicitly dealt with in the model, Table 6 presents a series of additional results. These results refer to estimations that include further controls to our baseline specification or that restrict the sample in other alternative ways. The table presents only the main coefficients of interest (value of coffee or agricultural production per capita and the wage of the head of the household), but we also discuss other results in the text (not presented in the table) below. ${ }^{18}$

The first column in the table includes as additional controls (in both $x_{i}$ and $z_{i}$ ) variables related to family structure, which are not modeled explicitly in our theory, but which may affect allocation of time or allocation of resources within the household. These may be related to demand for household work, substitution of domestic or market labor across different members of the household or dilution of family resources across different children. In order to account for these possibilities, we include as additional independent variables a dummy indicating whether both parents work, a dummy indicating whether the household has only one parent present, three dummy variables indicating the presence of siblings aged between 0 and 5, between 6 and 9 , and between 15 and 18, a dummy indicating the presence of and elderly person in the household, and a variable indicating total number of children present in the household. The main results are virtually unchanged by the inclusion of these variables. Among the family structure variables, number of children in the household, the presence of a sibling aged between 15 and 18, and the fact that both parents work are all associated with worse allocations of time for children, towards

\footnotetext{
${ }^{18}$ Results not reported are available upon request.
} 
more work and less schooling. The other variables do not have robust and significant effects across the different specifications.

The second column in Table 6 restricts the sample to only sons and daughters of the head of the household, to avoid the comparison of children who may be treated differently by the main family unit in the household. The third column, in sequence, changes the definition of child labor to at least 15 hours of work a week at some point during the previous year, to characterize a stronger attachment to the labor market. In both cases, results remain very similar to those obtained with the baseline specification.

The fourth, fifth, and sixth columns control for factors that may be associated to municipality characteristics and also to the incidence of child labor. In the fourth column, we introduce fixed-effects for what the Brazilian Census Bureau (IBGE) calls medium-regions ("meso-regiões"), which are geographic areas much smaller than states. ${ }^{19}$ In our case, the average number of municipalities per medium-region is 3.3 in the coffee production and 4.4 in the agricultural production sample. Medium-regions are sets of contiguous municipalities that share similar geographic and economic conditions. The fifth column includes as independent variables the natural logarithm of GDP per capita and population, both measured at the municipality level. These may capture changes in local development and urbanization levels that may be correlated to changes in agricultural production, and therefore could bias the results. The sixth column then includes state or geographic region-specific time dummies, in order to account for the possibility of differential trends in coffee or agricultural production across the different areas of the country (see the previous footnote on the reasons why we use state-specific time dummies in one case and geographic region-specific time dummies in the other). The results remain significant and of the same order of magnitude in all cases. Particularly, in the case of the coffee production sample, quantitative results are almost identical in the first two cases, and then

\footnotetext{
${ }^{19}$ The high degree of non-linearity in the generalized ordered logit model stops us from introducing a large number of fixed-effects in the model. When we include municipality fixed-effects, for example, the maximum likelihood procedure fails to converge in several specifications, while the estimated coefficients become highly unstable in the few specifications that do converge (according to changes in the sample and control variables). This is why we choose to report the results using medium-region fixed-effects, which control for local heterogeneity without introducing the problem of estimating a large number of parameters in a highly non-linear setting. In addition, these fixed-effects control for local heterogeneity still leaving some degree of variation in the independent variables measured at the municipality level (this minimizes the problems discussed by Deaton, 1997, p.107-8, related to the increase in standard errors and in the imprecision of estimates when the variation in the independent variable of interest is relatively modest across-time within municipality). The non-linearity is a recurrent problem in the estimation of generalized ordered logit models, and tends to be even worse in the probit case (see Williams, 2006). We face a similar problem when estimating state-specific time dummies, when these fail entirely to converge in the case of the coffee production sample. In this case, we replace state-specific by geographic region-specific time dummies (according to the IBGE's geographic classification of Brazil: North, Northeast, Centre-west, Southeast, and South). Also, a simple multinomial logit model does converge in this case, leading to results that are qualitatively similar to those reported in the table.
} 
increase somewhat when we control for geographic region time dummies. In the case of the agricultural production sample, quantitative results are reduced a little when we include mediumregion fixed effects or municipality characteristics, but the reduction is modest and significance is still maintained.

For the coffee production sample, we also check the robustness of the results to the definition of areas affected by coffee production. In the seventh column, we restrict the sample to municipalities in the top $40 \%$ of coffee producing municipalities. Again, results remain significant and quantitatively similar, though there is a small reduction in the coefficient on the value of coffee production per capita and a more substantial reduction in the coefficient on the wage of the head of the household.

Finally, the last two columns in Table 6 present results when the generalized ordered logit model is estimated without the imposition of any constraint on its coefficients. For the case of the coffee production sample, results seem to be quite similar to those obtained under the estimation with constraints. For the agricultural production sample, the coefficients on the value of agricultural production per capita are also quite similar to those obtained with the constraints, but the ones on the wage of the head of the household are quantitatively quite different and, surprisingly, not significant in the first transition equation. In more rigorous terms, in both samples we cannot reject, at the 5 percent significance level, the hypothesis of equality across transition equations of the coefficients on the value of coffee production and on the wage of the head of the household. ${ }^{20}$ Overall, we cannot reject the constraints imposed by our very simple theoretical model.

\section{Additional Results}

As a final exercise, we estimate our baseline specification for boys and girls separately, and also for children in a different age group (15 to 18 years of age). These results are presented in Table 7. As one might expect, boys' responses to shocks to local economic activity are more elastic than girls' (columns 1 and 2). This is true for both samples (coffee and agricultural production) and for both age groups. In relation to the response of the different genders to changes in the wage of the head of the household, there is no clear pattern. Girls seem to be more

\footnotetext{
${ }^{20}$ For the coffee production sample, the p-value for the joint Wald test for equality of coefficients across the different transition equations is 0.07 ; for the equality between the coefficients on the wage of the head of the household only, the p-value is 0.38 , while for the equality between the coefficients on the value of coffee production only, it is 0.06 . For the agricultural production sample, the p-value for the joint Wald test for equality of coefficients across the different transition equations is also 0.07 ; for the equality between the coefficients on the wage of the head of the household only, the p-value is 0.03 , while for the equality between the coefficients on the value of agricultural production only, it is 0.42 .
} 
sensitive to the wage of the head of the household, but results are reversed in one of the specifications and differences are relatively modest in others. Overall, older kids seem to be slightly less responsive to shocks to local economic activity, maybe because they are already engaged on market work on a more systematic basis (column 3). But opposite results are also obtained in the case of boys between 15 and 18 years of age (column 4). In any case, both quantitative and qualitative results are roughly similar across age groups and genders, and are also quite close to the results obtained in our baseline specification.

\section{Concluding Remarks}

In this paper, we develop a simple theoretical model of household choices regarding child labor and schooling. The theory characterizes the household problem in a way that can be represented by a generalized ordered discrete choice model, in which families can choose between three alternative allocations of children's time: work only, work together with schooling, and schooling only.

We apply the model to Brazil, using agricultural shocks to local economic activity (from coffee production and overall agricultural production) as a way to distinguish between the roles of increases in family wealth (income effect) and in the opportunity cost of children's time (substitution effect) in determining the incidence of child labor. We find that household characteristics associated with higher permanent income and wealth (or to less dependence on child's income) - hourly wage and job tenure of the head of the household, other sources of income, and household infrastructure - are associated with lower incidence of child labor and higher school attendance. At the same time, conditional on household wealth and socioeconomic characteristics, and on long-term trends, increases in labor demand due to shocks to local economic activity increase the opportunity cost of children's time, therefore increasing the incidence of child labor and reducing school attendance.

Our approach trusts more heavily on theory than the previous empirical literature on child labor. As a consequence, we are able to understand the reasons behind some of its seemingly conflicting results. We argue that our evidence related to family wealth and socioeconomic status, and to increases in the short-term demand for labor, isolate, respectively, the income and substitution effects present in different types of shocks faced by families. Generally, we show that, in order to understand the effect of a certain change in income or in the level of economic activity, one must understand how it affects the full income of the household and the opportunity cost of children's time. Only by understanding how a given shock affects these two dimensions 
of the family problem one is able to understand its implications in terms of child labor and schooling.

\section{References}

Baland, Jean-Marie e James A. Robinson (2000). Is Child Labor Inefficient? Journal of Political Economy, v108, n4, 663-79.

Barros, Ricardo, Rosane Mendonça, and Tatiana Velazco (1994). "Is Poverty the Main Cause of Child Work in Urban Brazil?" Instituto de Pesquisa Econômica Aplicada, Working Paper No.351.

Basu, Kaushik and Pham Hoang Van (1998). The Economics of Child Labor. American Economic Review, v88, n3, 412-27.

Becker, Gary S. (1981). A Treatise on the Family. Harvard University Press, Cambridge.

Beegle, Kathleen, Rajeev H. Dehejia and Roberta Gatti (2006). Child Labor and Agricultural Shocks, Journal of Development Economics, forthcoming.

Black, Dan A., Terra G. McKinnish and Seth G. Sanders (2003). Does the Availability of HighWage Jobs for Low-Skilled Men Affect Welfare Expenditures? Evidence from Shocks to the Steel and Coal Industries. Journal of Public Economics, v87, n910, 1921-1942.

Bourguignon, François, Francisco H. G. Ferreira, and Phillippe G. Leite (2003). Condtitional Cash Tranfers, Schooling, and Child Labor: Micro-Simulating Brazil's Bolsa Escola Program. World Bank Economic Review, v17, n2, 229-254.

Cardoso, Eliana and André P. Souza (2004). "The Impact of Cash Transfers on Child Labor and School Attendance in Brazil." Vanderbilt University, Department of Economics Working Paper No. 04-W07.

Deaton, Angus (1997). The Analysis of Household Surveys - A Microeconometric Approach to Development Policy. World Bank and Johns Hopkins University Press, Baltimore.

Dessy, Sylvain E. (2000). A Defense of Compulsive Measures against Child Labor. Journal of Development Economics, v62, n1, 261-75.

Duryea, Suzanne, and Mary P. Arends-Kuenning, (2003). School Attendance, Child Labor, and Local Labor Markets in Urban Brazil. World Development, v31, n7, 1165-78.

Edmonds, Eric V. (2005a). Does Child Labor Decline with Improving Economic Status? Journal of Human Resources, v40, n1, 77-99.

Edmonds, Eric V. (2005b). Child Labor and Schooling Responses to Anticipated Income in South Africa. Journal of Development Economics, forthcoming.

Emerson, Patrick M., and André P. Souza (2003). Is There a Child Labor Trap? Intergenerational Persistence of Child Labor in Brazil. Economic Development and Cultural Change, v51, n2, 375-98.

Gunnarsson, Victoria, Peter F. Orazem and Mario A. Sánchez (2006). Child Labor and School Achievement in Latin America, The World Bank Economic Review, v20, n1, 31-54.

Kruger, Diana (2006a). Child Labor and Schooling During a Coffee Sector Boom: Nicaragua 1993-1998. In: L.F. Lopez-Calva (ed). Trabjo Infantil: Teoría y Evidencia desde Latinoamerica, Fondo de Cultura Económica de México, Mexico, forthcoming. 
Kruger, Diana (2006b). Coffee Production Effects on Child Labor and Schooling in Rural Brazil, Journal of Development Economics, forthcoming.

Levison, Deborah, Karine S. Moe and Felicia Marie Knaul (2000). Youth Education and Work in Mexico. World Development, v29, n1, 167-88.

Neri, Marcelo C. and Mark Thomas (2001). "Household Responses to Labor-Market Shocks in Brazil, 1982-99.” Unpublished Manuscript, Fundação Getúlio Vargas.

Ranjan, Priya (2001). Credit constraints and the Phenomenon of Child Labor. Journal of Development Economics, v64, n1, 81-102.

Rogers, Carol Ann, and Kenneth A. Swinnerton (2004). Does Child Labor Decrease when Parental Income Rise? Journal of Political Economy, v112, n4, 939-46.

Schultz, T. Paul (1985). Changing World Prices, Women's Wages, and the Fertility Transition: Sweden, 1860-1910. Journal of Political Economy, v93, n6, 1126-1154.

Williams, Robert (2006). Generalized Ordered Logit/Partial Proportional Odds Models for Ordered Dependent Variables. The Stata Journal, v6, n1, 58-82. 
Fig. 1: Distribution of weekly hours worked (Coffee sample)

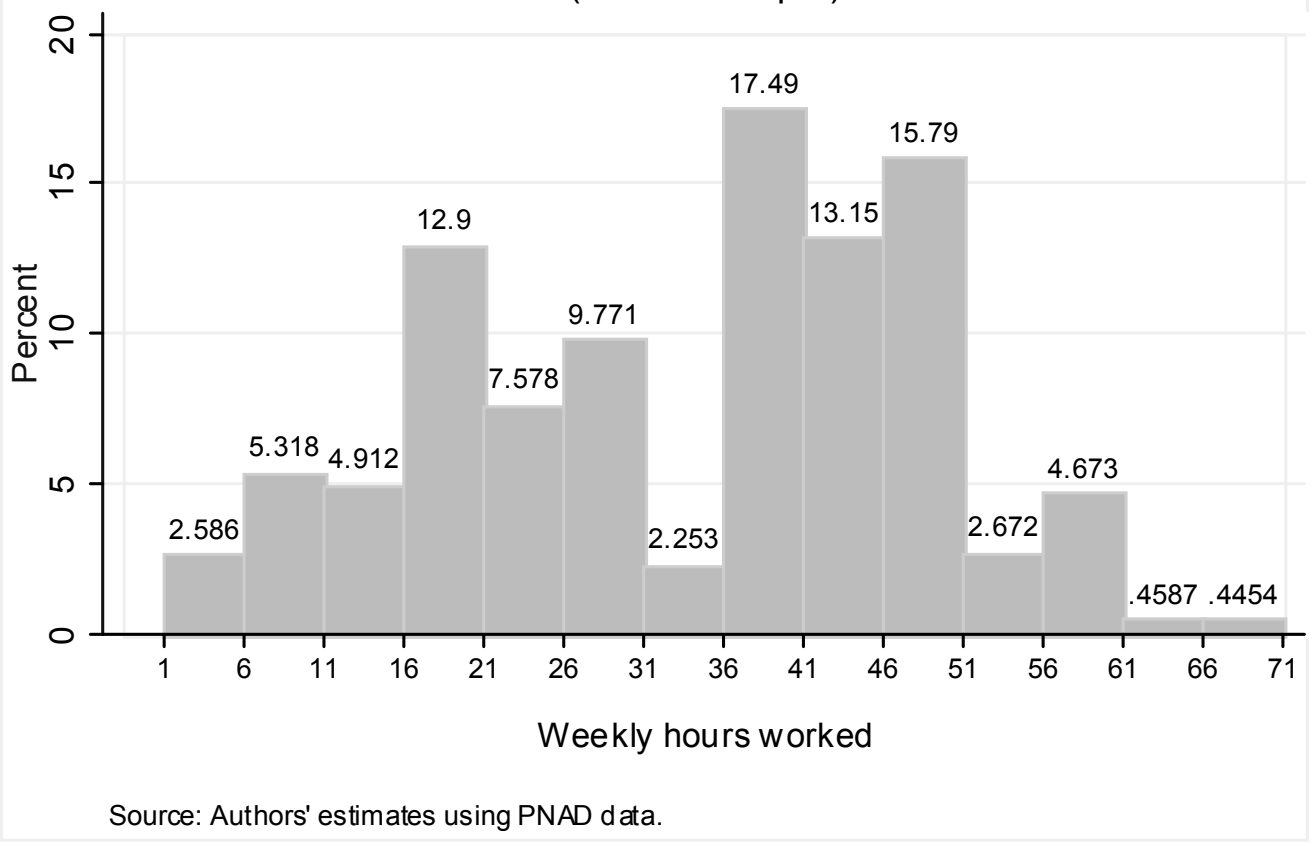

Fig. 2: Distribution of weekly hours worked

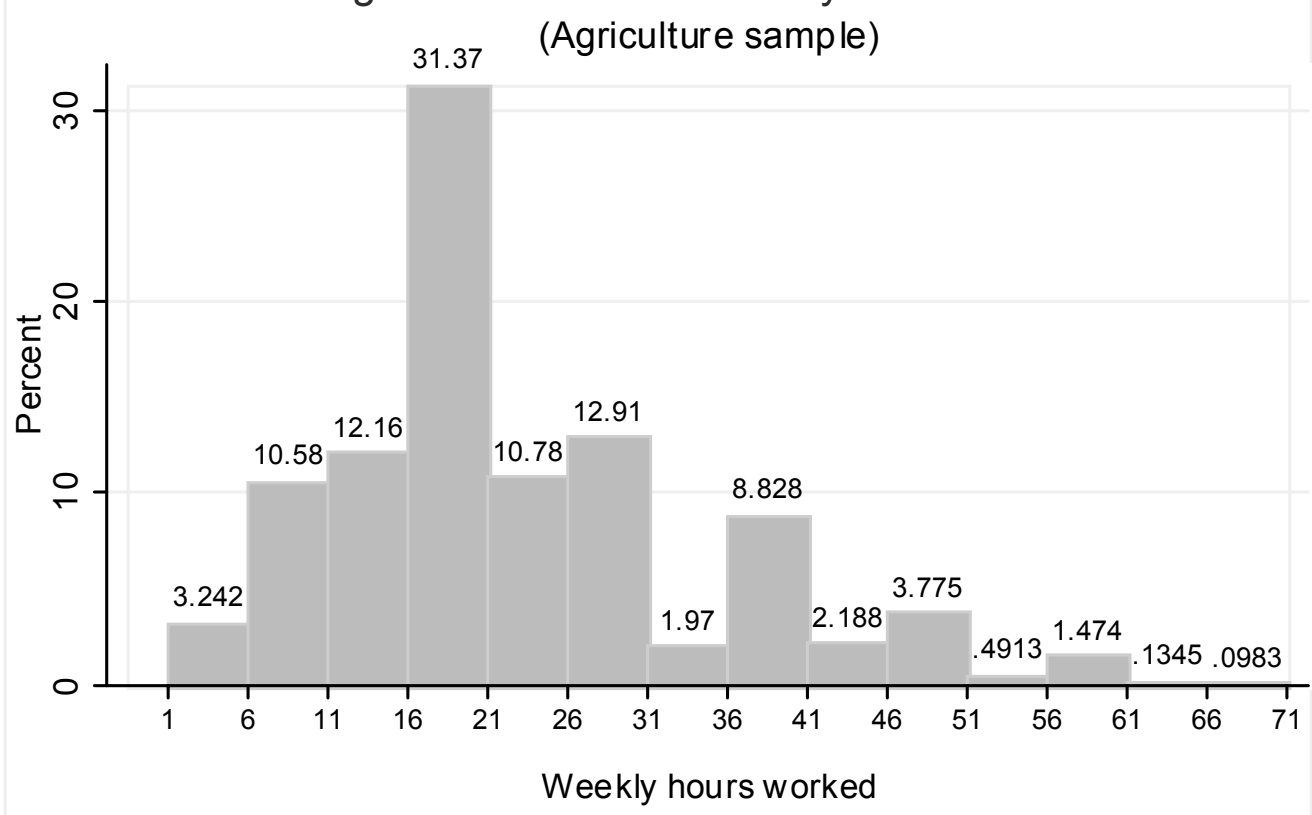

Source: Authors' estimates using PNAD data. 
Table 1: Distribution of Children by Year (\%), Brazil, 1993-2003

\begin{tabular}{|c|c|c|c|c|}
\hline \multicolumn{5}{|c|}{ Coffee Production Sample } \\
\hline Year & \multicolumn{3}{|c|}{ Work Only Work \& School School Only } & N. Obs. \\
\hline 1993 & 11.50 & 22.87 & 65.63 & 3,157 \\
\hline 1995 & 6.95 & 21.66 & 71.39 & 3,223 \\
\hline 1996 & 4.50 & 17.01 & 78.49 & 2,892 \\
\hline 1997 & 3.79 & 17.85 & 78.36 & 3,036 \\
\hline 1998 & 3.56 & 17.27 & 79.17 & 2,919 \\
\hline 1999 & 2.74 & 18.34 & 78.92 & 2,993 \\
\hline 2001 & 1.77 & 10.91 & 87.32 & 2,714 \\
\hline 2002 & 1.30 & 12.73 & 85.97 & 2,773 \\
\hline 2003 & 0.71 & 11.34 & 87.95 & 2,664 \\
\hline Total & 4.25 & 16.9 & 78.84 & 26,371 \\
\hline \multicolumn{5}{|c|}{ Agricultural Production Sample } \\
\hline Year & Work Only & Work \& School & School Only & N Obs \\
\hline 1993 & 14.81 & 37.01 & 48.18 & 6,077 \\
\hline 1995 & 12.22 & 38.21 & 49.56 & 6,202 \\
\hline 1996 & 9.7 & 30.6 & 59.7 & 5,585 \\
\hline 1997 & 6.18 & 34.45 & 59.38 & 6,105 \\
\hline 1998 & 4.64 & 35.52 & 59.84 & 5,929 \\
\hline 1999 & 3.73 & 37.7 & 58.57 & 6,252 \\
\hline 2001 & 2.56 & 36.08 & 61.36 & 4,690 \\
\hline 2002 & 2.21 & 35.32 & 62.48 & 4,669 \\
\hline 2003 & 1.84 & 32.76 & 65.4 & 4,359 \\
\hline Total & 6.79 & 35.42 & 57.79 & 49,868 \\
\hline \multicolumn{5}{|c|}{$\begin{array}{l}\text { Notes: Sample restricted to children aged btwn } 10 \text { and } 14 \text { related to head of the } \\
\text { household (heads of household restricted to full employed and aged btwn } 18 \text { and } \\
\text { 65). Coffee production sample restricted to municipalities with less than } 100,000 \\
\text { inhabitants in top } 60 \% \text { of coffee producing municipalities, and agricultural production } \\
\text { sample restricted to rural households. Data from PNAD and IBGE agricultural } \\
\text { surveys. }\end{array}$} \\
\hline
\end{tabular}


Table 2: Yearly Coffee and Agricultural Production per capita, Brazilian Municipalities included in the Sample, 1993-2003

\begin{tabular}{c|cc|cc}
\hline \hline & \multicolumn{3}{|c|}{ Coffee } & \multicolumn{2}{c}{ Agricultural } \\
\hline Year & $\begin{array}{c}\text { Production per } \\
\text { capita }\end{array}$ & $\begin{array}{c}\text { Number of } \\
\text { Municip. }\end{array}$ & $\begin{array}{c}\text { Production per } \\
\text { capita }\end{array}$ & $\begin{array}{c}\text { Number of } \\
\text { Municip. }\end{array}$ \\
\hline 1993 & 107.29 & 142 & 516.46 & 539 \\
1995 & 150.64 & 143 & 483.73 & 545 \\
1996 & 157.05 & 142 & 453.11 & 543 \\
1997 & 194.14 & 142 & 451.67 & 542 \\
1998 & 206.56 & 141 & 474.04 & 543 \\
1999 & 213.14 & 140 & 487.39 & 544 \\
2001 & 94.55 & 140 & 422.37 & 418 \\
2002 & 125.54 & 139 & 509.39 & 414 \\
2003 & 123.09 & 139 & 641.84 & 415 \\
\hline \hline
\end{tabular}

Notes: Production per capita in $2000 \mathrm{R} \$$ (reais). Sample restricted to children aged btwn 10 and 14 related to head of the household (heads of household restricted to full employed and aged btwn 18 and 65). Coffee production sample restricted to municipalities with less than 100,000 inhabitants in top $60 \%$ of coffee producing municipalities, and agricultural production sample restricted to rural households. Data from PNAD and IBGE agricultural surveys. 
Table 3: Summary Statistics, Brazil, 1993-2003

\begin{tabular}{|c|c|c|c|c|c|c|c|c|c|c|}
\hline \multirow[t]{2}{*}{ Variable } & \multicolumn{5}{|c|}{$\begin{array}{c}\text { Coffe Production Sample } \\
\text { Std. }\end{array}$} & \multicolumn{5}{|c|}{$\begin{array}{l}\text { Agricultural Production Sample } \\
\text { Std. }\end{array}$} \\
\hline & Obs & Mean & Dev. & Min & Max & Obs & Mean & Dev. & Min & Max \\
\hline \multicolumn{11}{|l|}{ Income variables } \\
\hline Value of Coffe Production p.c. & 26,371 & 95.8 & 200.5 & 0 & 2343 & & & & & \\
\hline Value of Agricultural GDP p.c. & & & & & & 49,868 & 688.3 & 1263.6 & 0 & 24568 \\
\hline Hourly wage of head of household & 26,371 & 1.6 & 2.8 & 0 & 172 & 49,868 & 0.9 & 1.7 & 0 & 94 \\
\hline Years of Education & 26,371 & 4.4 & 1.9 & 0 & 17 & 49,868 & 3.4 & 2.0 & 0 & 17 \\
\hline Female & 26,371 & 0.49 & 0.50 & 0 & 1 & 49,868 & 0.47 & 0.50 & 0 & 1 \\
\hline Mixed & 26,371 & 0.43 & 0.50 & 0 & 1 & 49,868 & 0.56 & 0.50 & 0 & 1 \\
\hline Black & 26,371 & 0.05 & 0.21 & 0 & 1 & 49,868 & 0.04 & 0.20 & 0 & 1 \\
\hline Age & 26,371 & 12.0 & 1.4 & 10 & 14 & 49,868 & 12.0 & 1.4 & 10 & 14 \\
\hline Lives in rural area & 26,371 & 0.29 & 0.46 & 0 & 1 & 49,868 & 1.00 & 0.00 & 1 & 1 \\
\hline Family Characteristics & & & & & & & & & & \\
\hline Age of head of household & 26,371 & 41.7 & 8.0 & 18 & 65 & 49,868 & 43.2 & 8.4 & 18 & 65 \\
\hline Education of head of hous. (years) & 26,371 & 5.5 & 4.2 & 0 & 17 & 49,868 & 3.2 & 3.0 & 0 & 17 \\
\hline $\begin{array}{l}\text { Female head of household } \\
\text { Wealth Characteristics }\end{array}$ & 26,371 & 0.25 & 0.44 & 0 & 1 & 49,868 & 0.19 & 0.39 & 0 & 1 \\
\hline Bedrooms per person & 26,336 & 0.49 & 0.16 & 0.07 & 1.50 & 49,754 & 0.45 & 0.15 & 0.08 & 1.75 \\
\hline Has electricitiy & 26,337 & 0.92 & 0.27 & 0 & 1 & 49,753 & 0.69 & 0.46 & 0 & 1 \\
\hline Has Telephone & 26,326 & 0.26 & 0.44 & 0 & 1 & 49,747 & 0.05 & 0.21 & 0 & 1 \\
\hline Has television & 26,313 & 0.83 & 0.38 & 0 & 1 & 49,732 & 0.59 & 0.49 & 0 & 1 \\
\hline Has refrigerator & 26,336 & 0.75 & 0.43 & 0 & 1 & 49,745 & 0.46 & 0.50 & 0 & 1 \\
\hline $\begin{array}{l}\text { Has washing machine } \\
\text { Tenure of head of household }\end{array}$ & $\begin{array}{l}26,339 \\
26,371\end{array}$ & 0.21 & 0.41 & 0 & 1 & 49,752 & 0.08 & 0.27 & 0 & 1 \\
\hline (months) & & 109 & 109 & 0 & 696 & 49,868 & 163 & 144 & 0 & 696 \\
\hline $\begin{array}{l}\text { Other income of household } \\
\text { Family Structure }\end{array}$ & 26,371 & 36 & 149 & 1 & 7,025 & 49,868 & 25 & 91 & 1 & 7,025 \\
\hline Both parents work & 26,371 & 0.32 & 0.47 & 0 & 1 & 49,868 & 0.31 & 0.46 & 0 & 1 \\
\hline Head of the hous. is single parent & 26,371 & 0.09 & 0.29 & 0 & 1 & 49,868 & 0.06 & 0.24 & 0 & 1 \\
\hline Sibs. 0-5 years living in household & 26,371 & 0.30 & 0.46 & 0 & 1 & 49,868 & 0.37 & 0.48 & 0 & 1 \\
\hline Sibs.6-9 years living in household & 26,371 & 0.42 & 0.49 & 0 & 1 & 49,868 & 0.51 & 0.50 & 0 & 1 \\
\hline Sibs $15-18$ years living in household & 26,371 & 0.39 & 0.49 & 0 & 1 & 49,868 & 0.45 & 0.50 & 0 & 1 \\
\hline Total number of siblings & 26,371 & 1.43 & 1.28 & 0 & 9 & 49,868 & 1.91 & 1.58 & 0 & 12 \\
\hline Elderly member present & 26,371 & 0.04 & 0.19 & 0 & 1 & 49,868 & 0.05 & 0.21 & 0 & 1 \\
\hline
\end{tabular}


Table 4 : Household Choices of Child Labor and Schooling - Generalized Ordered Logits, Brazil, 1993-2003

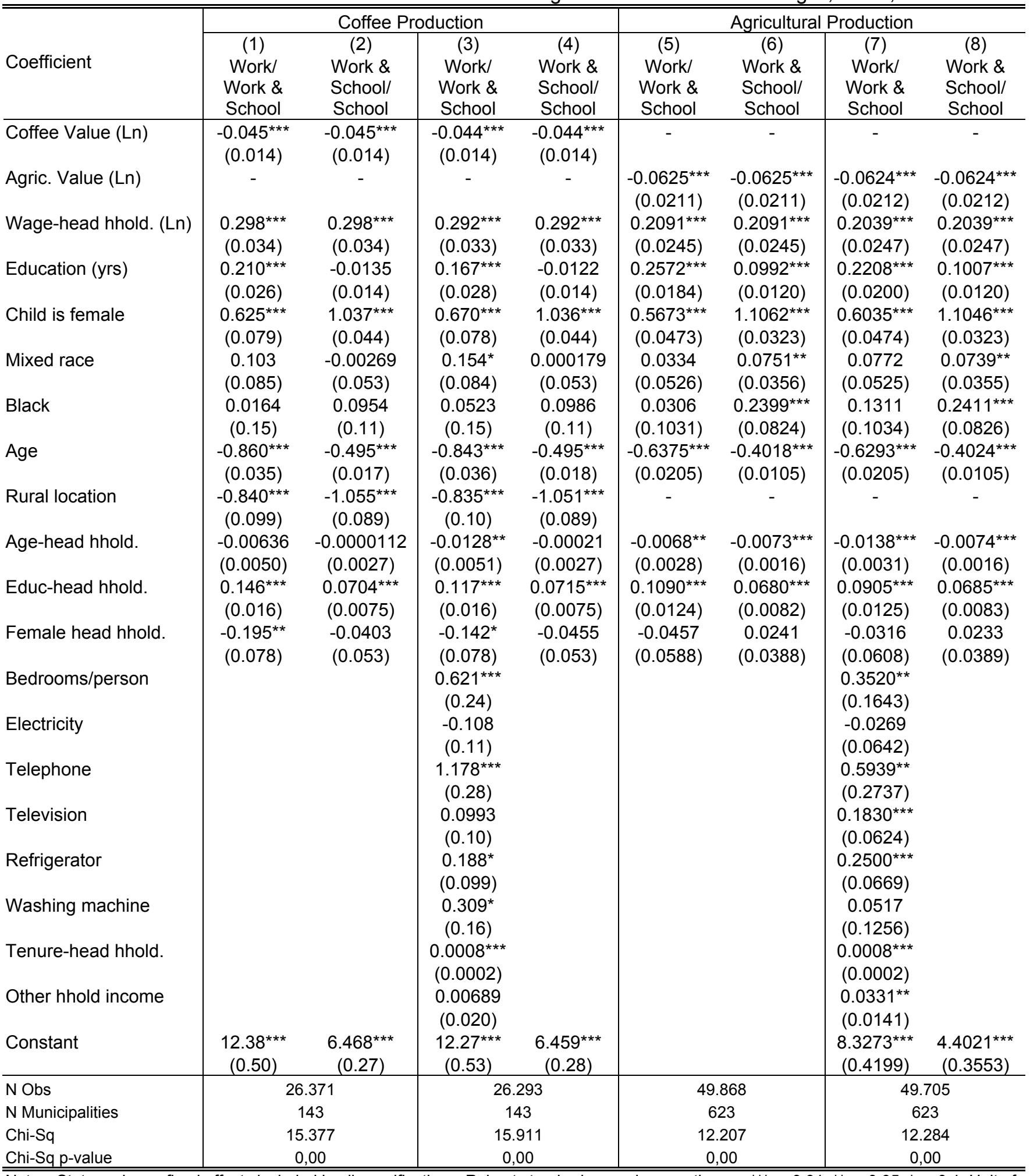

Notes: State and year fixed effects included in all specifications. Robust standard errors in parentheses. ${ }^{* * *} p<0.01,{ }^{* *} p<0.05,{ }^{*} p<0.1$. Unit of observation is child. Dep var is categorical indicating whether child works only (0), works and goes to school (1), or goes to school only (2). Indep vars are value of municipality coffee or agricultural production per capita (In), hourly wage of head of household (In), education, female dummy, race dummies (mixed and black), age, rural dummy, age of head of household, education of head of household, female head of household dummy, number of bedrooms per capita, dummies indicating whether household has electricity, phone, tv, fridge, and washing machine, tenure of head of household in current job, other income of household (In). Sample restricted to children aged btwn 10 and 14 related to head of the household (heads of household restricted to full employed and aged btwn 18 and 65). Coffee production sample restricted to municipalities with less than 100,000 inhabitants in top $60 \%$ of coffee producing municipalities, and agricultural production sample restricted to rural households. Robust standard errors clustered at municipality level. Data from PNAD and IBGE agricultural surveys. 
Table 5: Household Choices of Child Labor and Schooling - Generalized Ordered Logits Marginal Effects, Brazil, 1993-2003

\begin{tabular}{|c|c|c|c|c|c|c|}
\hline \multirow[b]{2}{*}{ Coefficient } & \multicolumn{3}{|c|}{ Coffee Production } & \multicolumn{3}{|c|}{ Agricultural Production } \\
\hline & $\begin{array}{c}\text { (1) } \\
\text { Work Only }\end{array}$ & $\begin{array}{c}(2) \\
\text { Work- } \\
\text { School }\end{array}$ & $\begin{array}{c}(3) \\
\text { School } \\
\text { Only }\end{array}$ & $\begin{array}{l}(4) \\
\text { Work } \\
\text { Only }\end{array}$ & $\begin{array}{c}5) \\
\text { Work \& } \\
\text { School }\end{array}$ & $\begin{array}{c}(6) \\
\text { School } \\
\text { Only }\end{array}$ \\
\hline Coffee Value (Ln) & $\begin{array}{c}0,00039^{\star \star \star} \\
(0,00013)\end{array}$ & $\begin{array}{c}0,00516^{\star * *} \\
(0,00166)\end{array}$ & $\begin{array}{l}-0,00555^{\star * *} \\
(0,00179)\end{array}$ & - & - & - \\
\hline Agric. Value (Ln) & - & - & - & $\begin{array}{c}0,00196^{* * *} \\
(0,00065)\end{array}$ & $\begin{array}{c}0,01304^{* * *} \\
(0,00442)\end{array}$ & $\begin{array}{l}-0,01500^{* * *} \\
(0,00507)\end{array}$ \\
\hline Wage-head hhold. (Ln) & $\begin{array}{l}-0,00260^{* * *} \\
(0,00034)\end{array}$ & $\begin{array}{c}-0,0341^{* * *} \\
(0,00389)\end{array}$ & $\begin{array}{l}0,03672^{\star \star \star} \\
(0,00415)\end{array}$ & $\begin{array}{l}-0,00640^{* * *} \\
(0,00077)\end{array}$ & $\begin{array}{l}-0,04258^{\star \star \star} \\
(0,00515)\end{array}$ & $\begin{array}{c}0,04898^{\star * *} \\
(0,00588)\end{array}$ \\
\hline Education (yrs) & $\begin{array}{l}-0,00148^{\star * *} \\
(0,00029)\end{array}$ & $\begin{array}{c}0,00302^{*} \\
(0,00174)\end{array}$ & $\begin{array}{r}-0,00154 \\
(0,00181)\end{array}$ & $\begin{array}{l}-0,00693^{\star * *} \\
(0,00067)\end{array}$ & $\begin{array}{l}-0,01726^{\star \star \star} \\
(0,00273)\end{array}$ & $\begin{array}{c}0,02418^{\star * *} \\
(0,00286)\end{array}$ \\
\hline Child is female & $\begin{array}{l}-0,00602^{* * *} \\
(0,00087)\end{array}$ & $\begin{array}{l}-0,12423^{\star \star \star} \\
(0,00629)\end{array}$ & $\begin{array}{c}0,13025^{\star * *} \\
(0,00656)\end{array}$ & $\begin{array}{l}-0,01890^{* * *} \\
(0,00151)\end{array}$ & $\begin{array}{l}-0,23931^{\star \star *} \\
(0,00694)\end{array}$ & $\begin{array}{c}0,25821^{\text {*** }} \\
(0,00733)\end{array}$ \\
\hline Mixed race & $\begin{array}{c}-0,00136^{*} \\
(0,00073)\end{array}$ & $\begin{array}{r}0,00134 \\
(0,00646)\end{array}$ & $\begin{array}{r}0,00002 \\
(0,00663)\end{array}$ & $\begin{array}{r}-0,00243 \\
(0,00166)\end{array}$ & $\begin{array}{l}-0,01534^{*} \\
(0,00834)\end{array}$ & $\begin{array}{c}0,01778^{* *} \\
(0,00854)\end{array}$ \\
\hline Black & $\begin{array}{r}-0,00046 \\
(0,00130)\end{array}$ & $\begin{array}{l}-0,01155 \\
(0,01285)\end{array}$ & $\begin{array}{r}0,01201 \\
(0,01351)\end{array}$ & $\begin{array}{r}-0,00389 \\
(0,00289)\end{array}$ & $\begin{array}{l}-0,05256^{\star \star \star} \\
(0,01777)\end{array}$ & $\begin{array}{c}0,05645^{\star * *} \\
(0,01876)\end{array}$ \\
\hline Age & $\begin{array}{c}0,00751^{* * *} \\
(0,00066)\end{array}$ & $\begin{array}{c}0,05468^{* * *} \\
(0,00218)\end{array}$ & $\begin{array}{l}-0,06219^{* * *} \\
(0,00230)\end{array}$ & $\begin{array}{c}0,01974^{* * *} \\
(0,00081)\end{array}$ & $\begin{array}{c}0,07693^{\star * \star} \\
(0,00244)\end{array}$ & $\begin{array}{l}-0,09667^{* * *} \\
(0,00247)\end{array}$ \\
\hline Rural location & $\begin{array}{l}0,00906^{* * *} \\
(0,00150)\end{array}$ & $\begin{array}{c}0,14480^{* * *} \\
(0,01499)\end{array}$ & $\begin{array}{l}-0,15386^{* * *} \\
(0,01561)\end{array}$ & - & - & - \\
\hline Age-head hhold. & $\begin{array}{c}0,00011^{* * *} \\
(0,00005)\end{array}$ & $\begin{array}{r}-0,00009 \\
(0,00032)\end{array}$ & $\begin{array}{r}-0,00003 \\
(0,00034)\end{array}$ & $\begin{array}{c}0,00043^{* * *} \\
(0,00010)\end{array}$ & $\begin{array}{c}0,00135^{\star * *} \\
(0,00038)\end{array}$ & $\begin{array}{l}-0,00179^{\star * *} \\
(0,00039)\end{array}$ \\
\hline Educ-head hhold. & $\begin{array}{l}-0,00104^{* * *} \\
(0,00016)\end{array}$ & $\begin{array}{l}-0,00795^{\star * *} \\
(0,00091)\end{array}$ & $\begin{array}{c}0,00899^{* * *} \\
(0,00094)\end{array}$ & $\begin{array}{l}-0,00284^{* * *} \\
(0,00039)\end{array}$ & $\begin{array}{l}-0,01361^{\star \star \star} \\
(0,00190)\end{array}$ & 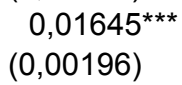 \\
\hline Female head hhold. & $\begin{array}{c}0,00131^{*} \\
(0,00076)\end{array}$ & $\begin{array}{r}0,00445 \\
(0,00658)\end{array}$ & $\begin{array}{r}-0,00576 \\
(0,00677)\end{array}$ & $\begin{array}{r}0,00100 \\
(0,00194)\end{array}$ & $\begin{array}{r}-0,00659 \\
(0,00890)\end{array}$ & $\begin{array}{r}0,00559 \\
(0,00932)\end{array}$ \\
\hline Bedrooms/person & $\begin{array}{l}-0,00553^{* * *} \\
(0,00216)\end{array}$ & $\begin{array}{c}0,00553^{\star * *} \\
(0,00216)\end{array}$ & & $\begin{array}{l}-0,01104^{* *} \\
(0,00517)\end{array}$ & $\begin{array}{c}0,01104^{* *} \\
(0,00517)\end{array}$ & \\
\hline Electricity & $\begin{array}{r}0,00092 \\
(0,00092)\end{array}$ & $\begin{array}{r}-0,00092 \\
(0,00092)\end{array}$ & & $\begin{array}{r}0,00084 \\
(0,00199)\end{array}$ & $\begin{array}{r}-0,00084 \\
(0,00199)\end{array}$ & \\
\hline Telephone & $\begin{array}{l}-0,00842^{* * *} \\
(0,00139)\end{array}$ & $\begin{array}{c}0,00842^{* * *} \\
(0,00139)\end{array}$ & & $\begin{array}{l}-0,01462^{* * *} \\
(0,00512)\end{array}$ & $\begin{array}{c}0,01462^{* * *} \\
(0,00512)\end{array}$ & \\
\hline Television & $\begin{array}{r}-0,00091 \\
(0,00101)\end{array}$ & $\begin{array}{r}0,00091 \\
(0,00101)\end{array}$ & & $\begin{array}{l}-0,00584^{* * *} \\
(0,00203)\end{array}$ & $\begin{array}{c}0,00584^{\star \star *} \\
(0,00203)\end{array}$ & \\
\hline Refrigerator & $\begin{array}{c}-0,00176^{*} \\
(0,00096)\end{array}$ & $\begin{array}{c}0,00176^{*} \\
(0,00096)\end{array}$ & & $\begin{array}{l}-0,00779^{* * *} \\
(0,00207)\end{array}$ & $\begin{array}{c}0,00779^{\star \star \star} \\
(0,00207)\end{array}$ & \\
\hline Washing machine & $\begin{array}{l}-0,00253^{\star * *} \\
(0,00122)\end{array}$ & $\begin{array}{c}0,00253^{\star \star \star} \\
(0,00122)\end{array}$ & & $\begin{array}{r}-0,00159 \\
(0,00378)\end{array}$ & $\begin{array}{r}0,00159 \\
(0,00378)\end{array}$ & \\
\hline Tenure-head hhold. & $\begin{array}{l}-0,00001^{* * *} \\
(0,00000)\end{array}$ & $\begin{array}{c}0,00001^{* * *} \\
(0,00000)\end{array}$ & & $\begin{array}{l}-0,00002^{* * *} \\
(0,00001)\end{array}$ & $\begin{array}{c}0,00002^{\star \star \star} \\
(0,00001)\end{array}$ & \\
\hline Other hhold income & $\begin{array}{r}-0,00006 \\
(0,00018) \\
\end{array}$ & $\begin{array}{r}0,00006 \\
(0,00018) \\
\end{array}$ & & $\begin{array}{l}-0,00104^{* *} \\
(0,00045)\end{array}$ & $\begin{array}{c}0,00104^{\star *} \\
(0,00045)\end{array}$ & \\
\hline Obs. Freq. & 0,042 & 0,169 & 0,789 & 0,068 & 0,354 & 0,578 \\
\hline $\begin{array}{l}\text { N Obs } \\
\text { N Municipalities } \\
\text { Chi-Sq } \\
\text { Chi-Sq p-value }\end{array}$ & & $\begin{array}{c}26.293 \\
143 \\
15911 \\
0,00\end{array}$ & & & $\begin{array}{c}49.705 \\
623 \\
12284 \\
0,00\end{array}$ & \\
\hline
\end{tabular}

Notes: Robust standard errors in parentheses. ${ }^{* * *} p<0.01,{ }^{* *} p<0.05,{ }^{*} p<0.1$. Unit of observation is child. Effect of change in indep. variable on prob. of outcome (complete specification in Table 4). Indep vars are value of municip. coffee or agric. production per capita (In), hourly wage of head of household (In), education, female dummy, race dummies (mixed and black), age, rural dummy, age of head of household, education of head of household, female head of household dummy, bedrooms per capita, dummies indicating whether household has electricity, phone, tv, fridge, and washing machine, tenure of head of household in current job, other income of household (In), and state and year fixed effects. Sample described in Table4. Data from PNAD and IBGE agricultural surveys. 
Table 6: Robustness Checks for Household Choices of Child Labor and Schooling - Generalized Ordered Logits, Brazil, $1993-2003$

\begin{tabular}{|c|c|c|c|c|c|c|c|c|c|c|}
\hline \multirow[b]{2}{*}{ Sample } & \multirow[b]{2}{*}{ Coefficient } & \multirow[b]{2}{*}{$\begin{array}{c}\text { Family } \\
\text { Structure } \\
(1) \\
\end{array}$} & \multirow[b]{2}{*}{$\begin{array}{c}\text { Sons and } \\
\text { Daughters } \\
(2) \\
\end{array}$} & \multirow[b]{2}{*}{$\begin{array}{c}\geq 15 \text { Hours } \\
\text { of Weekly } \\
\text { Work } \\
(3) \\
\end{array}$} & \multirow[b]{2}{*}{$\begin{array}{c}\text { Meso- } \\
\text { region F.E. } \\
(4) \\
\end{array}$} & \multirow[b]{2}{*}{$\begin{array}{c}\text { Municipality } \\
\text { Charact. } \\
\text { (5) } \\
\end{array}$} & \multirow[b]{2}{*}{$\begin{array}{c}\text { State/Region- } \\
\text { Specific Time } \\
\text { Dummies } \\
(6) \\
\end{array}$} & \multirow[b]{2}{*}{$\begin{array}{c}\text { Top } 40 \% \\
\text { Coffee } \\
\text { Production } \\
(7) \\
\end{array}$} & \multicolumn{2}{|c|}{ No Constraints } \\
\hline & & & & & & & & & $\begin{array}{c}\text { Work } \\
\text { Work \& } \\
\text { School } \\
(8) \\
\end{array}$ & $\begin{array}{c}\text { Work \& } \\
\text { School/ } \\
\text { School } \\
(9) \\
\end{array}$ \\
\hline \multirow{3}{*}{$\begin{array}{c}\text { Coffee } \\
\text { Production }\end{array}$} & $\begin{array}{l}\text { Coffee } \\
\text { Value (Ln) }\end{array}$ & $\begin{array}{l}-0.0419 * * * \\
(0.014)\end{array}$ & $\begin{array}{l}-0.0447^{* * *} \\
(0.014)\end{array}$ & $\begin{array}{l}-0.0524^{* * *} \\
(0.013)\end{array}$ & $\begin{array}{l}-0.0451^{* * *} \\
(0.015)\end{array}$ & $\begin{array}{l}-0.0428^{* *} \\
(0.0173)\end{array}$ & $\begin{array}{l}-0.0688^{* * *} \\
(0.015)\end{array}$ & $\begin{array}{l}-0.0380^{* *} \\
(0.017)\end{array}$ & $\begin{array}{l}-0.0726^{* * *} \\
(0.015)\end{array}$ & $\begin{array}{l}-0.0407^{* * *} \\
(0.014)\end{array}$ \\
\hline & $\begin{array}{l}\text { Wage-head } \\
\text { hhold. (Ln) }\end{array}$ & $\begin{array}{l}0.284^{* * *} \\
(0.034)\end{array}$ & $\begin{array}{l}0.2819^{* * *} \\
(0.033)\end{array}$ & $\begin{array}{l}0.2501^{* * *} \\
(0.035)\end{array}$ & $\begin{array}{l}0.276^{\star * *} \\
(0.035)\end{array}$ & $\begin{array}{l}0.299 * * * \\
(0.0528)\end{array}$ & $\begin{array}{l}0.3132^{* * *} \\
(0.0324)\end{array}$ & $\begin{array}{l}0.178^{* * *} \\
(0.036)\end{array}$ & $\begin{array}{l}0.151^{* *} \\
(0.062)\end{array}$ & $\begin{array}{l}0.206^{* * *} \\
(0.036)\end{array}$ \\
\hline & $\mathrm{N}$ Obs & 26.293 & 25.468 & 26.098 & 26.293 & 11.336 & 26.293 & 20.673 & 26.293 & 26.293 \\
\hline \multirow{3}{*}{$\begin{array}{l}\text { Agricultural } \\
\text { Production }\end{array}$} & $\begin{array}{l}\text { Agric. } \\
\text { Prodn. } \\
\text { Value (Ln) }\end{array}$ & $\begin{array}{l}-0.0635^{* * *} \\
(0.0207)\end{array}$ & $\begin{array}{l}-0.0628^{* * *} \\
(0.021)\end{array}$ & $\begin{array}{l}-0.0688^{* * *} \\
(0.021)\end{array}$ & $\begin{array}{l}-0.0482^{* *} \\
(0.0237)\end{array}$ & $\begin{array}{l}-0.0424^{\star *} \\
(0.0215)\end{array}$ & $\begin{array}{l}-0.0624^{* * *} \\
(0.0216)\end{array}$ & - & $\begin{array}{l}-0.0648^{* * *} \\
(0.0215)\end{array}$ & $\begin{array}{l}-0.0471^{* *} \\
(0.0189)\end{array}$ \\
\hline & $\begin{array}{l}\text { Wage-head } \\
\text { hhold. (Ln) }\end{array}$ & $\begin{array}{l}0.1878^{* * *} \\
(0.0250)\end{array}$ & $\begin{array}{l}0.2048^{* * *} \\
(0.024)\end{array}$ & $\begin{array}{l}0.1664^{* * *} \\
(0.023)\end{array}$ & $\begin{array}{l}0.1843^{* * *} \\
(0.0224)\end{array}$ & $\begin{array}{l}0.2468^{* * *} \\
(0.0339)\end{array}$ & $\begin{array}{l}0.2087^{* * *} \\
(0.0249)\end{array}$ & - & $\begin{array}{l}0.0428 \\
(0.0291)\end{array}$ & $\begin{array}{l}0.1154^{* * *} \\
(0.0259)\end{array}$ \\
\hline & $\mathrm{NObs}$ & 49.705 & 48.134 & 49.245 & 49.705 & 21.134 & 49.705 & & 49.705 & 49.705 \\
\hline
\end{tabular}

Notes: Robust standard errors in parentheses. ${ }^{* \star *} p<0.01,{ }^{* \star} p<0.05,{ }^{*} p<0.1$. Unit of observation is child. Dep var is categorical indicating whether child works only (0), works and goes to school (1), or goes to school only (2). Indep vars include all controls from Table 4 (not shown). Family structure includes dummies for both parents working, single parent household,

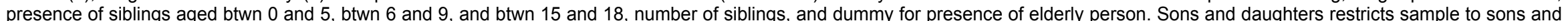

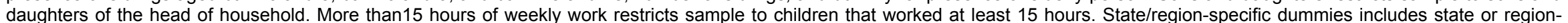
specific time dummies (maximum likelihood in the cofee sample did not converge with state-specific dummies). Municip. charact. includes In(gdp per capita) and pop. Last two columns, respectively, restrict sample to municip. in top $40 \%$ of coffee production and estimate complete model from Table 2 without constraints. Initial samples identical to that of Table 4 . Robust standard errors clustered at municipality level. Data from PNAD and IBGE agricultural surveys. 
Table 7: Additional Results for Household Choices of Child Labor and Schooling - Generalized Ordered Logits, Brazil, 1993-2003

\begin{tabular}{|c|c|c|c|c|c|c|}
\hline Sample & Coefficient & $\begin{array}{c}(1) \\
\text { Boys } \\
\end{array}$ & $\begin{array}{c}(2) \\
\text { Girls } \\
\end{array}$ & $\begin{array}{c}(3) \\
\text { Ages 15-18 } \\
\end{array}$ & $\begin{array}{c}(4) \\
\text { Boys 15-18 } \\
\end{array}$ & $\begin{array}{c}(5) \\
\text { Girls 15-18 } \\
\end{array}$ \\
\hline \multirow{3}{*}{$\begin{array}{c}\text { Coffee } \\
\text { Production }\end{array}$} & $\begin{array}{l}\text { Coffee Value } \\
\text { (Ln) }\end{array}$ & $\begin{array}{l}-0.0477^{* * *} \\
(0.015)\end{array}$ & $\begin{array}{l}-0.0371^{\text {** }} \\
(0.019)\end{array}$ & $\begin{array}{l}-0.0355^{\star * *} \\
(0.013)\end{array}$ & $\begin{array}{l}-0.0401^{\text {***}} \\
(0.012)\end{array}$ & $\begin{array}{l}-0.0299^{*} \\
(0.017)\end{array}$ \\
\hline & $\begin{array}{l}\text { Wage-head } \\
\text { hhold. (Ln) }\end{array}$ & $\begin{array}{l}0.263^{* * *} \\
(0.038)\end{array}$ & $\begin{array}{l}0.351^{* * *} \\
(0.053)\end{array}$ & $\begin{array}{l}0.270^{* * *} \\
(0.027)\end{array}$ & $\begin{array}{l}0.252^{* * *} \\
(0.033)\end{array}$ & $\begin{array}{l}0.295^{* * *} \\
(0.041)\end{array}$ \\
\hline & N Obs & 13.534 & 12.759 & 17.205 & 9.588 & 7.617 \\
\hline \multirow{3}{*}{$\begin{array}{l}\text { Agricultural } \\
\text { Production }\end{array}$} & $\begin{array}{l}\text { Agric. Prodn. } \\
\text { Value (Ln) }\end{array}$ & $\begin{array}{l}-0.0690^{* * *} \\
(0.0227)\end{array}$ & $\begin{array}{l}-0.0510^{* *} \\
(0.0218)\end{array}$ & $\begin{array}{l}-0.0639^{* * *} \\
(0.0155)\end{array}$ & $\begin{array}{l}-0.0758^{* * *} \\
(0.0176)\end{array}$ & $\begin{array}{l}-0.0467^{* * *} \\
(0.0167)\end{array}$ \\
\hline & $\begin{array}{l}\text { Wage-head } \\
\text { hhold. (Ln) }\end{array}$ & $\begin{array}{l}0.2178^{* * *} \\
(0.0265)\end{array}$ & $\begin{array}{l}0.1956^{\star * *} \\
(0.0326)\end{array}$ & $\begin{array}{l}0.1267^{* * *} \\
(0.0213)\end{array}$ & $\begin{array}{l}0.1085^{* \star *} \\
(0.0263)\end{array}$ & $\begin{array}{l}0.1558^{\star * \star} \\
(0.0300)\end{array}$ \\
\hline & N Obs & 26.090 & 23.615 & 30.556 & 18.213 & 12.343 \\
\hline
\end{tabular}

Notes: Robust standard errors in parentheses. ${ }^{* * *} p<0.01,{ }^{* *} p<0.05,{ }^{*} p<0.1$. Unit of observation is child. Dep var is categorical indicating whether child works only (0), works and goes to school (1), or goes to school only (2). Indep vars include all controls from Table 4 (not shown). Basic coffee production sample restricted to municipalities with less than 100,000 inhabitants in top $60 \%$ of coffee producing municipalities, and agricultural production sample restricted to rural households. Robust standard errors clustered at municipality level. Data from PNAD and IBGE agricultural surveys. Sample restricted to children aged btwn 10 and 14 related to head of household (heads of household restricted to full employed and aged btwn 18 and 65). Additional results restrict sample to, respectively, boys, girls, children btwn 15 and 18, boys btwn 15 and 18, and girls btwn 15 and 18 . 